
THE

AUTOBIOGRAPHY

OF

SOLOMON

MAIMON 



\title{
THE \\ AUTOBIOGRAPHY \\ OF
}

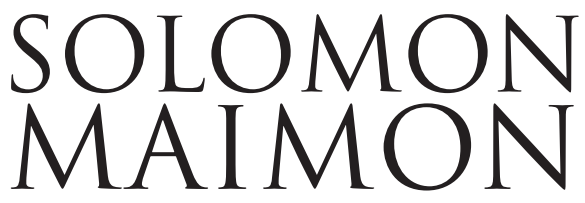

THE COMPLETE TRANSLATION

\author{
EDITED BY \\ YITZHAK Y. MELAMED \& \\ ABRAHAM P. SOCHER \\ TRANSLATED BY \\ PAUL REITTER \\ WITH AN AFTERWORD BY \\ GIDEON FREUDENTHAL
}

PRINCETON U N IVERSITY PRESS

PRINCETON AND OXFORD 
Copyright (C) 2018 by Princeton University Press

Published by Princeton University Press

41 William Street, Princeton, New Jersey 08540

6 Oxford Street, Woodstock, Oxfordshire OX20 1TR

press.princeton.edu

All Rights Reserved

\section{$\mathrm{LCCN}$}

ISBN 978-0-691-16385-7

British Library Cataloging-in-Publication Data is available

Editorial: Fred Appel and Thalia Leaf

Production Editorial: Karen Carter

Text Design: Lorraine Betz Doneker

Jacket/Cover Design: Lorraine Betz Doneker

Jacket/Cover Credit:

Production:

Publicity:

Copyeditor:\{ ? CE: please add your name if you would like it included; otherwise delete this line

This book has been composed in Sabon and Trajan for display

Printed on acid-free paper. $\infty$

Printed in the United States of America

135779108642 


\title{
CONTENTS
}

\author{
Acknowledgments ix \\ Translator's Note xi \\ A Guide to Reading Maimon's Autobiography xiii
}

Original Editor's Preface, by Karl Philipp Moritz xxxvii

Introduction 1

Chapter 1: My Grandfather's Household 4

Chapter 2: Earliest Childhood Memories 11

Chapter 3: Private Education and Independent Study 13

Chapter 4: Jewish Schools. The Joy of Being Delivered from Them Results in a Stiff Foot 19

Chapter 5: My Family Is Driven into Poverty, and an Old Servant's Great Loyalty Costs Him a Christian Burial 22

Chapter 6: New Residence, New Misery. The Talmudist 24

Chapter 7: Happiness Turns Out to Be Short-Lived 28

Chapter 8: The Student Knows More Than the Teacher. A Theft a la Rousseau Is Discovered. The Pious Man Wears What the Godless Man Procures 31

Chapter 9: Love Affairs. Marriage Proposals. The Song of Solomon

Can Be Used as a Matchmaking Device. Smallpox 34

Chapter 10: People Fight over Me. I Suddenly Go from Having No

Wives to Having Two. In the End, I Wind Up Being Kidnapped 37

Chapter 11: Marrying as an Eleven Year Old Makes Me into My Wife's

Slave and Results in Beatings at the Hands of My Mother-in-Law.

A Spirit of Flesh and Blood 41

Chapter 12: Marital Secrets. Prince R., or the Things One Isn't Allowed to Do in Poland 44

Chapter 13: Striving for Intellectual Growth amidst the Eternal Struggle against All Kinds of Misery 49

Chapter 14: I Study the Kabbalah, and Finally Become a Doctor 52

Chapter 15: Brief Account of the Jewish Religion, from Its Origins

to the Present 62

Chapter 16: Jewish Piety and Exercises in Penance 75

Chapter 17: Friendship and Rapture 78

Chapter 18: Life as a Tutor 82 
Chapter 19: Another Secret Society and Therefore a Long Chapter

Chapter 20: Continuation of the Story, as well as Some Thoughts on Religious Mysteries 101

Chapter 21: Trips to Königsberg, Stettin, and Berlin, to Further My Understanding of Humanity 108

Chapter 22: My Misery Reaches Its Nadir. Rescue 113

\section{Preface to the Second Book 121}

Introduction: Expansion of My Knowledge and Development of My Character. On Both the Writings of the Famous Rabbi Moses

Ben Maimon Had the Greatest Influence. Precise Account of These Writings 127

Chapter 1: More Newochim: Its Plan, Goal, and Method. Theologica Politica 133

Chapter 2: Continuation. Interpretation of Expressions with Multiple Meanings. Language in the Hands of Theologians, like Clay in the Hands of the Potters. Anti-Rousseauean Refutation of an Objection. Cautionary Rule for Aspiring Metaphysicians: One Must First Learn to Swim before Plunging into the Great Oceans of the World 140

Chapter 3: Continuation. The Crow Is Robbed of the Feathers Stolen from Other Birds, or the Denial of God's Positive Characteristics 147

Chapter 4: Continuation. Explanation of the Manifold Names of God as Names for His Actions. Destiny of Metaphysics. It Becomes the Slave of Theology. Its Degeneration into Dialectics 152

Chapter 5: Continuation. The Concept of Angels. Some Remain at Their Stations as Ambassadors, Others Have Been Ordered Back. Genesis and Influence of the Uniform Beings. Aristotelians' Reasons for the Eternity of the World 161

Chapter 6: Continuation. Counter-Reasons. A Psychological Explanation of Prophesy That Doesn't Undermine the Dignity of Prophesy 167

Chapter 7: Continuation. Relation of All Natural Events to God.

A Very Comfortable and Pious Method. Divine Equipage, a Cosmological Idea That the Prophet Ezekiel Wouldn't Have Dreamed of. Excellent Morals, but Not in Line with Today's Taste. Origins of Evil. Prophesy. Final Causes 172

Chapter 8: Continuation. Overcoming Doubts about God's Omniscience. The Book of Job as the Vehicle for a Metaphysical Treatise on Providence 177

Chapter 9: Mosaic Jurisprudence. The Silly Paganism of the Sabians, an Impetus to Many Otherwise Inexplicable Laws, of Which the Beard Still Remains 181 
Chapter 10: Conclusion of the More Newochim. Excellent Morals.

Definition of the True Worship of God, Which Makes Priests

Unnecessary 186

Admonition 189

Chapter 11: My Arrival in Berlin. Acquaintances. Mendelssohn.

Doubting Metaphysical Systems. Teaching Locke and Adelung 192

Chapter 12: Mendelssohn. A Chapter Dedicated to the Memory of a Great Friend 198

Chapter 13: My Initial Aversion to Belle Lettres and My Ensuing

Conversion. Departure from Berlin. A Stay in Hamburg. I Get

Drunk the Way a Bad Actor Shoots Himself. A Foolish Old

Woman Falls in Love with Me-and Is Rejected 205

Chapter 14: I Return to Hamburg. A Lutheran Pastor Calls Me

a Mangy Sheep and Claims That I Am Unworthy of Being Taken

into the Christian Flock. I Become a Gymnasium Student

and Make the Chief Rabbi as Mad as a Ram 215

Chapter 15: Third Journey to Berlin. Failed Plan to Become a Hebrew

Author. Journey to Breslau. Divorce 222

Chapter 16: Fourth Trip to Berlin. Atrocious Conditions and Help.

Study of Kant's Writings. A Depiction of My Own Works 230

Concluding Chapter: The Merry Masquerade Ball 240

Afterword: Maimon's Philosophical Itinerary 245

Abbreviations 263

Bibliography 265

Index 273 



\section{ACKNOWLEDGMENTS}

WE ARE GRATEFUl to the many friends of ours and of Solomon Maimon's who have insisted that a complete annotated translation of his great autobiography should exist and have helped us to bring it into existence. Among them, we should particularly like to acknowledge the members of a wonderful seminar on a draft of this text at the Skeptical Atelier of the Maimonides Centre for Advanced Studies at the University of Hamburg: Leora Batnitzky, Daniel Dragicevic, Florian Ehrensperger, Warren Zev Harvey, Moshe Idel, who also delivered a remarkable public address on Maimon's relationship to Kabbala, Patrick Koch, Ada Rapaport-Albert, Oded Schechter, Shaul Stampfer, Josef Stern, Mate Veres, Dirk Westerkamp, and Professor Stephan Schmid, co-director of the Institute. We are also grateful to Giusepe Veltri for graciously hosting us at the remarkable institution he has done so much to build. Damion Searls, a remarkably skilled translator, read the manuscript and offered many incisive suggestions for improvement. This galaxy of linguistic, philosophical, and historical talent notwithstanding, this book would not exist without the patient support of our editor Fred Appel and the rest of the editorial team at Princeton University Press, especially Karen Carter and Thalia Leaf. The same can be said of our editorial assistant Jason Yanover, who is already a significant scholar of German Idealism in his own right. We are also very grateful to Brittany Micka-Foos, who gave us much good counsel in copyediting the manuscript and was a pleasure to work with.

A number of scholars generously responded to our queries and requests for advice, and we want to thank them, too: Frederick Beiser, Moishi Chechik, Jonathan Garb, Matt Goldish, Elhanan Reiner, Abraham Abish Shor, Scott Spector, and Liliane Weissberg.

Our debts to our spouses, who have had to live with this project for so long, is incalculable. The autobiography of a wayward husband may not be an entirely appropriate gift, nonetheless we dedicate this book to Maria, Neta, and Shoshana.

Paul Reitter

Yitzhak Melamed Abraham Socher 



\section{TRANSLATOR'S NOTE}

Friedrich SCHLEIERMACHER, a great theorist of translation, once claimed that the experience of reading a translation should be like that of reading in a language in which you are fluent, but of which you are not a native speaker. In other words, a translation should seem a little foreign. How, then, to translate a text that already seems a little foreign in the original language? Should you accentuate its foreignness so that readers of the translation, who might expect some foreignness from a translation, will understand that in this case, there is a foreignness even in the original? But when the foreignness we are talking about isn't, say, some kind of dialect, marked as such by context, are readers likely to keep the original's foreignness in mind from line to line? Might not the translation wind up coming across as ponderous, rather than as purposively non-colloquial? Furthermore, non-dialect foreignness is a broad category. How to produce echoes of the particular foreignness in question?

I thought a lot about these issues as I rendered Maimon's autobiography into English. For while Maimon's German prose is grammatical, and often elevated in its selection of words and expressions, it isn't quite colloquial. Its proficiency is due in part to the editorial efforts of Maimon's friend Karl Phillip Moritz: As has often been noted, the autobiographical fragments that Maimon published in the Journal of Empirical Psychology are much rougher. But in the fragments Maimon was going for a different effect-that of an authentic case study as opposed to the perspective of the autobiography, which is that of a man who has overcome the intellectual and material privation of his youth to develop into an accomplished, if erratic, person of letters. It's unclear how much he relied on Moritz in his attempt to create a style consistent with the latter aim.

In truth, Maimon was a linguistic shape-shifter whose level of German proficiency changed according to the occasion and who was very aware of the sort of scrutiny to which his German was subjected, especially from German Jews. Indeed, one of the most famous scenes in the Autobiography involves Maimon recounting how, upon reaching Berlin for the first time, his broken speech, unpolished manners, and wild gesticulations resulted in his cutting a bizarre figure, like a "starling" that "has learned to say a few words." What breathes out of Maimon's evocation of the scene isn't so much resentment as an air of superiority and passiveaggressive delight. Having slyly alluded to Aristotle's definition of man (i.e., the "talking animal"), Maimon tells of how he, the underdog, bested 
Markus Herz, his cultivated and thoroughly stunned Jewish partner in debate. For Maimon himself, though, the outcome should not have been surprising. While his outsider status caused him no small measure of hardship, and while the Autobiography frequently ridicules the Eastern European Jewish culture into which its author was born, Maimon was also critical of the Jewish acculturation he encountered in Berlin, seeing it as intellectually limiting. It may be in part for this reason that there can be something mocking in Maimon's use of German colloquialisms and formal expressions. Language was the key vehicle of acculturation, and Maimon's, as Hannah Arendt suggested, was a pariah's acculturation. One could even say that it has elements of what other theorists would call colonial mimicry.

In the translation, I have tried to convey this. I have also tried to avoid the great temptation that attends retranslation. Or more specifically, I have tried to avoid the temptation that attends retranslation when, as is the case here, a key text has been translated into English just once and without as much fidelity as one might reasonably hope for: to write in reaction to the existing translation. Whether I have succeeded, or to what degree, is of course for readers to judge. 


\section{A GUIDE TO READING MAIMON'S AUTOBIOGRAPHY}

Midway through George Eliot's last novel, Daniel Deronda (1876), the title character, a Jewish orphan raised as an English aristocrat, wanders into a secondhand bookshop in East London and finds "something that he wanted-namely that wonderful piece of autobiography, the life of the Polish Jew Solomon Maimon." Eliot, who had translated those more famous Jewish heretics, Benedict Spinoza (who Maimon had read closely) and Heinrich Heine (who had read Maimon closely), left an annotated copy of Salomon Maimons Lebensgeschichte in her library. ${ }^{1}$ She was far from alone as an appreciative reader of Maimon's autobiography, which is, as the literary historian Alan Mintz remarked, "one of those rare works that legitimately deserves to be called seminal." 2

Contemporary readers of Maimon's autobiography included Goethe and Schiller, but it made the greatest impression on nineteenth-century Eastern European Jewish readers who had suffered a similar crisis of faith and were struggling to modernize Jewish culture or find their feet outside of it. Thus, Mordechai Aaron Guenzberg (1795-1846) and Moshe Leib Lilienblum (1843-1910) both saw Maimon as their great predecessor, the archetype of the modern Jewish heretic, or apikores, who had described the pathologies of traditional Jewish society and made a successful—or almost successful—break with it. Both of them patterned their own influential Hebrew autobiographies after Maimon's Lebensgeschichte, as did the Yiddish philologist Alexander Harkavi (1863-1939) a generation later.

When the soon-to-be radical Nietzschean Zionist Micha Yosef Berdichevsky (1865-1921) left the great Yeshivah of Volozhin in the 1880 s, one of the first books he turned to was Maimon's autobiography. ${ }^{3}$

${ }^{1}$ George Eliot, Daniel Deronda (Hertfordshire, 1996), p. 320, and Israel Abrahams, "George Eliot and Solomon Maimon," in Abrahams, The Book of Delights and Other Papers (Philadelphia: Jewish Publication Society, 1911), pp. 242-46.

${ }^{2}$ Alan Mintz, Banished from Their Father's Table: Loss of Faith and Hebrew Autobiography (Bloomington: University of Indiana Press), p. 10, and see Marcus Mosely, Being for Myself Alone: Origins of Jewish Autobiography (Palo Alto: Stanford University Press, 2005), especially pp. 56-65.

${ }^{3}$ For Berdichevksy's appreciation for Maimon, see Kitvei Micha Yosef bin Gurion: Ma'amrim (Tel-Aviv, 1960), pp. 201-15. 
Prominent German-Jewish readers included the novelist Berthold Auerbach, who based a character upon him; the pioneering historian of Hasidism Aharon Marcus (Verus); and the twentieth-century thinkers Hannah Arendt, Walter Benjamin, Gershom Scholem, and Leo Strauss, all of whom had their first serious exposure to Maimonidean philosophy in the pages of Maimon's autobiography. ${ }^{4}$ Arendt went on to list Maimon as the first modern Jewish intellectual to adopt the role of the "conscious pariah," a role she saw as later having been taken up by Heine and Franz Kafka, among others. ${ }^{5}$ As an editor at Schocken, Arendt also helped bring Maimon to English readers by publishing an abridgement of an already-abridged nineteenth-century English translation of Maimon's autobiography. When the Jewish loss-of-faith genre was Americanized by Chaim Potok in The Chosen (1967), he explicitly modeled his brilliant, troubled Hasidic protagonist on Maimon. ${ }^{6}$ Potok had read the Schocken edition as a young man and then gone on to write a dissertation on Maimon as a philosopher ${ }^{7}$ before turning to fiction. $^{8}$

Historically speaking, Solomon Maimon stood at the cusp of Jewish modernity and passed through virtually all of the spiritual and intellectual options open to European Jews at the end of the eighteenth century. Literarily speaking, he is the first to have dramatized this position and attempted to understand it, and thus himself. His autobiography is not only the first modern Jewish work of its kind, it also combines an

\footnotetext{
${ }^{4}$ Conversely, the great twentieth-century rabbinic thinkers Yosef Rosen (the Rogatchover Gaon) and Rabbi Joseph Soloveitchik both had their first serious exposure to modern philosophy in Maimon's commentary to Maimonides' Guide of the Perplexed, Giv'at haMoreh (1791). Maimon's Giv'at ha-Moreh was, in fact, required reading in Soloveitchik's 1950-51 lectures on Maimonidian philosophy at Yeshiva University's Bernard Revel Graduate School of Jewish Studies. See Joseph B. Soloveitchik, Maimonides: Between Philosophy and Halakha (New York: Ktav, 2016), edited with an introduction by Lawrence J. Kaplan, pp. 40-41, 65-68.

${ }^{5}$ Hannah Arendt, “The Jew as Conscious Pariah: A Hidden Tradition,” Jewish Social Studies 6 (1944), pp. 98-117.

${ }^{6}$ The Jewish loss-of-faith, or "off the derech," memoir has had an extraordinary resurgence in the last few years. Among the most accomplished of these works are Deborah Feldman's Unorthodox: My Scandalous Rejection of My Hasidic Roots (New York: Simon and Schuster, 2012), and Shulem Deen's All Who Go Do Not Return (Minneapolis: Graywolf Press, 2015), neither of which seem to be aware of the history of the genre or of Maimon.

${ }^{7}$ Herman Potok, The Rationalism and Skepticism of Salomon Maimon. University of Pennsylvania, $\mathrm{PhD}$ thesis, 1965. His work was supervised by the distinguished Hebrew University philosophers, Hugo Bermann and Nathan Rotenstreich.

${ }^{8}$ This litany is meant to be suggestive of how important Maimon's autobiography was for modern Jewish literature and thought, not exhaustive. A full account of the book's reception history remains a desideratum. For a brief suggestive discussion, see Abraham P. Socher, The Radical Enlightenment of Solomon Maimon: Judaism, Heresy and Philosophy (Palo Alto: Stanford University Press, 2006), ch. 5.
} 
astonishingly deep knowledge of almost every branch of Jewish literature with an acute and highly original analysis of Judaism, its social and political dimensions, and its intellectual horizons.

He was born in 1753 in Sukoviborg, a small town on the tributary of the Niemen River, near the city of Mirz, in what was then the PolishLithuanian Commonwealth. ${ }^{9}$ Since Jews of that time and place did not commonly take surnames, his given name was simply Shelomo ben Yehoshua (Solomon son of Joshua). Indeed, he did not take the name of the great twelfth-century Jewish philosopher Moses ben Maimon (Maimonides) until he was close to thirty years old and studying at the liberal Gymnasium Christianeum in Altona, and then only in more or less formal German contexts, although one such context was the present autobiography, with which he fully introduced himself to the literary world. ${ }^{10}$

The Autobiography, simply titled Salomon Maimons Lebensgeschichte, was published in Berlin in two volumes in 1792 and $1793 .{ }^{11}$ It was edited by his friend Karl Philipp Moritz (1756-93), with whom he collaborated in editing a unique journal of psychology, parapsychology, and what we would call the social sciences more generally, whose full title was Gnothi Sauton, oder Magazin zur Erfahrungsseelenkunde als ein Lesebuch für Gelehrte und Ungelehrte (roughly: "Know Thyself, or the Magazine for Empirical Psychology as a Reader for the Learned and the Unlearned"). Indeed, Maimon's autobiography began as a contribution to the journal as an anonymous case study of a Polish Jew named "Salomon ben Josua," focusing on the social and economic arrangements under which he grew up as the grandchild of a Jewish leaseholder of the leading Polish-Lithuanian aristocrat, Prince Karol Stanislaw Radziwill (1734-90). ${ }^{12}$ It was only after writing

\footnotetext{
${ }^{9}$ The question of the year of Maimon's birth has been the subject of some dispute. We follow Sabbattia Wolff's early memoir, Maimoniana oder Rhapsodien zur Characteristik Salomon Maimons (Berlin, 1813), p. 10, although the date does not quite tally with some of Maimon's scattered remarks about his age, e.g., in September 1794 he wrote to Goethe that he was forty-two. See the discussion of P. Lahover in his introduction to the Hebrew translation of Y. L. Baruch, Hayyei Shelomo Maimon (Tel-Aviv, 1941), p. 9 n1.

${ }^{10}$ An undated twentieth-century brochure published by the Gymnasium contains the text of two educational certificates for Maimon, the first of which is dated November 1783, and describes Maimon as "a young man of the Jewish nation, named Solomon from Lithuania." The second, dated February 1785, refers to him as "Salomon Maimon, born in Lithuania," cited in Samuel Hugo Bergman, The Philosophy of Salomon Maimon, trans. Noah Jacobs (Jerusalem, 1967).

${ }^{11}$ Salomon Maimons Lebensgeschichte. Von ihm selbst geschrieben und herausgegeben von K. P. Moritz. In zwei Theilen. (Berlin: bei Friedrich Vieweg dem ältern, 1792-93).

12 "Fragmente aus Ben Josua's Lebensgeschichte. Herausgegeben von K. P. Moritz," Gnothi sauton oder Magazin zur Erfahrungsseelenkunde als ein Lesebuch für Gelehrte und Ungelehrte, Bd. 9/1 (1792), pp. 24-69.
} 
these third-person "fragments" of his life that Maimon found himself composing a more personal account of how, in "striving for intellectual growth . . . amidst all kinds of misery," he had become an influential, if idiosyncratic, contributor to the philosophical literature of the German and Jewish enlightenments. ${ }^{13}$

As its many readers over the last two centuries will attest, Maimon's autobiography really is, as Eliot (and Deronda) had said, "wonderful" - by turns a brilliantly vivid, informative, searing and witty, even hilarious account of his life as a Talmudic prodigy from-as he put it in a letter to Immanuel Kant- "the woods of Lithuania," a literally preadolescent husband, an aspiring kabbalist-magician, an earnest young philosopher, a bedraggled beggar, an urbane Berlin pleasure-seeker, and, eventually, the philosopher of whom Kant would write "none of my critics understood me and the main questions so well as Herr Maimon." In fact, some of the incidents and encounters Maimon narrates are so entertaining and incredible that one is tempted to read his book as a picaresque novel, a Jewish Tom Jones. Yet in virtually every instance in which it is possible to verify an incident, source a quotation, or identify a figure to whom he has coyly referred only with an initial-the drunken Polish Prince R., the charismatic "New Hasidic" preacher B. of M., the supercilious Jewish intellectual H., the censorious Chief Rabbi of Hamburg, as well as far less famous individuals-Maimon's account checks out. In our notes to Paul Reitter's excellent translation, we have tried to document this without being too obtrusive, or needlessly cluttering the text.

The only previous English translation of Maimon's Lebensgeschichte appeared in 1888. The translator, a professor of Moral Psychology at McGill University named J. Clark Murray, elided a few difficult passages in the first volume of the Autobiography and cut the preface and ten chapters on the philosophy of Moses Maimonides with which Maimon had prefaced the second volume. He also cut the comical, puzzling allegory with which Maimon concluded the second part of his autobiography. These chapters were, Murray wrote in his preface, not "biographical" and "excite just the faintest suspicion of 'padding" "14 Although Murray's translation has been reprinted, pared down, excerpted, and anthologized for well over a century now, Reitter's translation is, astonishingly, the first complete, accurate English translation of Maimon's autobiography

\footnotetext{
${ }^{13}$ The quote is taken from Maimon's heading for bk. 1, ch. 13, below p. XY. \{ ? PAGE Ref NEEDED

${ }^{14}$ J. Clark Murray, “Translator's Preface,” to Solomon Maimon, Autobiography (London, 1888), p. xxxvi.
} 
into English. ${ }^{15}$ In fact, both of the twentieth-century German editions, as well as the excellent Hebrew translation, consign Maimon's philosophical, theoretical, and historical chapters to appendices. ${ }^{16}$ Consequently, although Maimon's autobiography has been widely read and cited as one of the most important and interesting first-person accounts of both Jewish life and European thought at the cusp of modernity, few have read it as Maimon intended-despite the fact that it is his deeply self-conscious account of his own life and thought. ${ }^{17}$

Of course it is easy to understand why nineteenth-, twentieth-, and twenty-first-century readers would find it odd for a writer to place even a philosophically incisive ten-chapter summary of Moses Maimonides' medieval classic The Guide of the Perplexed at the center of his autobiography, and understandable that they would prefer Maimon's rollicking, bumptious, and bitterly sardonic accounts of his escape from his traditional upbringing (bizarre local superstitions, debauched noblemen, corrupt clerics, secret societies, and so on) to philosophical exposition. But here, as elsewhere, it is the odd detail of a text that is the key to its interpretation. After all, Maimon did take the great twelfthcentury philosopher's name as his own in an extraordinary act of literary homage (and chutzpa). Moreover, it turns out that his understanding of Maimonides' Guide is both philosophically astute and a key to understanding his book, both as an autobiography and as a critique of contemporary Judaism.

\footnotetext{
${ }^{15}$ Murray's translation of the Autobiography was further truncated by the distinguished classicist Moses Hadas for the publisher Schocken in 1947, reprinted in paperback in 1967. (Hadas was, incidentally, described by his student Norman Podhoretz as a "lapsed rabbi" in his autobiography, which was probably indebted to Maimon in its depiction of his journey from parochial Brooklyn to cosmopolitan Manhattan, see Making It (New York: Random House, 1967), p. 44.) Michael Shapiro republished and introduced a full version of the Murray translation for Illinois University Press in 2001, and the standard sourcebook for English-language courses in modern Jewish history, Paul Mendes-Flohr and Jehuda Reinharz, eds., The Jew in the Modern World: A Documentary History, 3rd ed. (Oxford: Oxford University Press, 2010), reproduces excerpts from Murray's translation, as does Lucy Davidowicz, The Golden Tradition: Jewish Life and Thought in Eastern Europe (Syracuse: Syracuse University Press, reprint ed., 1996).

16 Jakob Fromer, ed., Salomon Maimon's Lebensgeschichte (Munich, 1911); Zwi Batscha, ed., Salomon Maimon's Lebensgeschichte (Frankfurt: Insel Verlag, 1984), and see P. Lahover, ed., Hayyei Shelomo Maimon, trans. Y. L. Baruch (Tel-Aviv, 1941).

${ }^{17}$ For Paul Reitter's reflections on the challenges of translating Maimon, see, in addition to the translator's preface below, pp. $\mathrm{x}$-y, \{ ? $\sim$ PAGE REF NEEDED $\}$ his "The Autobiography of Solomon Maimon and the Task of the Retranslator," in his Bambi's Jewish Roots and Other Essays on German-Jewish Culture (London: Bloomsbury, 2015).
} 
As he writes in preface to these chapters:

The first part of this autobiography showed me striving to develop my humble capacities and my character. While the obstacles chance put in my way did slow this process, it did not block it altogether. And as every action must have an equal and opposite reaction, it seems in my case that these obstacles were an intentional device on the part of wise providence, which actually helped me in some ways to reach my goal. Lacking enlightened teachers and suitable readings, I had to learn to reflect for myself. The rarity of helpful texts taught me to value all the more those that I could get hold of. I felt compelled to give them my full attention, correct their mistakes, fill in their gaps, and try to bring light and order to their dark, confused chaos. ... Melancholic and ecstatic religion was slowly transformed into a religion of reason. The free cultivation of the capacity for knowledge and morality took the place of the slavish religious service. And I recognized perfection as being the precondition for true blessedness.

The writings of the famous Maimonides (Rabbi Moses Ben Maimon) were most influential in bringing about this happy transformation. My admiration for this great teacher reached the point that I regarded him as the ideal of a perfect human being and his doctrines as having been dictated by divine wisdom itself. $^{18}$

This passage is couched in the intellectual language of the Enlightenment, with its allusion to Newton's third law of motion, insistence upon thinking for oneself as the key to moral development, and disdain for melancholic and ecstatic (schwärmerisch) religion. But even here one can see both hints of Maimon's unique philosophical position and clues to the deep narrative structure that underlies the picaresque adventures he recounts. These can both be summed up in his idea of perfection (Vollkommenheit), which is not simply a vague ideal but a precise medieval Aristotelian doctrine he took from Maimonides, wrestled with all of his life, and employed in his influential attempt to revise Immanuel Kant's transcendental philosophy.

This doctrine is, for present purposes, that true knowledge of an object consists in contemplation of its essence or form. In such an act of cognition, not only is the knowledge identical to its object (since the object of knowledge is abstracted from its matter), but insofar as the knower is identified with this thought he (or she) too is a part of this identity. In this ideal sense, only God, or, more precisely, what Aristotelians call the Active Intellect, can be said to truly know something. In the act of knowing, says Maimonides in a passage Maimon will patiently explicate several

${ }^{18}$ See below preface to bk. 2, p. XYZ.\{ ? PAGE REF NEEDED\} 
times over his career, the "representing subject, His representations, and the objects He represents," are identical. ${ }^{19}$ Humans can only occasionally and fitfully approximate such epistemic perfection, but when they do and grasp (or are grasped by) a universal truth, they take part in the divine thought and receive at least a taste of immortality. This is the sort of perfection that Maimon says is "the precondition for true blessedness," a term that he takes from another great heretic who was deeply influenced by Maimonides' Guide on these matters, Benedict de Spinoza. ${ }^{20}$

Thus when Maimon says that he brought his earliest Hebrew philosophical manuscript in which he worked through this and related philosophical and kabbalistic doctrines, "as a monument of the human mind's striving for perfection, regardless of all the obstacles placed in its way," he means it both autobiographically and philosophically. ${ }^{21}$ Much of his earliest thinking was on the plausibility and ramifications of this ideal of perfection, and his autobiographical story is not just a string of adventures in which he bests establishment figures, fools, and frauds of all sorts, but the story of his attempt to attain this ideal.- Though, as we shall see, he will eventually conclude that it is a kind of regulative ideal, or necessary fiction, rather than a real human possibility. ${ }^{22}$

Maimon was well aware of how far this all was from the intellectual worlds of his peers in the overlapping Jewish and German Enlightenments (known, respectively as the Haskalah and Aufklärung). One can see this

${ }^{19}$ See below, bk. 2, ch. 4, p. XYZ, \{ ? PAGE REF NEEDED\}explicating the famous "knower, knowing, and the known" passage in Maimonides' Guide of the Perplexed, 1:68. Maimon, Giva't ha-Moreh, ch. 68, and Hesheq Shelomo, pp. 125-26.

${ }^{20} \mathrm{We}$ are aware that we are compressing a universe of metaphysics, epistemology, and theology into a teacup-sized paragraph for present expository purposes. This tradition begins with Aristotle's famously cryptic passage in De Anima 3:5 about cognitive activity (and passivity). For a classic discussion of its reception in medieval philosophy and Maimonides in particular, see Shlomo Pines, "Translator's Introduction," to his translation of the Guide of the Perplexed (Chicago, 1963).

${ }^{21}$ Although it was lost after the dissolution of the Hochschule für die Wissenschaft des Judentums by the Nazis, Maimon's manuscript, which he gave the biblical title Hesheq Shelomo (The Desire of Solomon), resurfaced in 1984 when it was revealed that the Hochschule rabbinics professor Alexander Guttman had smuggled a valuable cache of manuscripts with him to America in 1939 and was attempting to sell them in a Sotheby's auction. On the subsequent controversy over the disposition of the manuscripts, see H. C. Zafren, "From Hochschule to Judaica Conservancy Foundation: The Guttman Affair," Jewish Book Annual 47 (1989), pp. 6-26. Hesheq Shelomo is now held in the manuscript collection of the National Library of Israel, MS $8^{0} 6426$.

${ }^{22}$ On the ideal of perfection in Maimon, see the editor's introduction to Gideon Freudenthal, ed., Salomon Maimon: Rational Dogmatist, Empirical Skeptic (Dordrecht: Kluwer, 2003), p. 15. For an interpretation that makes it central, see Abraham P. Socher, The Radical Enlightenment of Solomon Maimon: Judaism, Heresy and Philosophy (Palo Alto: Stanford University Press, 2006), which this introduction draws upon and revises. 
in another passage in his preface to the second part of the Autobiography, which also highlights his inimitable voice:

I am not, to be sure, a great man, a world-class philosopher, or a buffoon. Nor have I ever suffocated mice, tortured frogs, or made a little man dance by shocking him with electricity. But what does that matter? I love the truth, and where the truth is at stake, I don't go around asking about the devil and his grandmother.

From the mere fact I left my people, my homeland, and my family to seek the truth, the reader will surely recognize that no petty motivations can have shaped my account of the truth. ${ }^{23}$

This is, in fact, both a deliberately buffoonish riff and a principled theoretical rejection of the worldly philosophy of fellow Enlightenment thinkers who are obsessed with the mastery of merely empirical phenomena (vacuum chambers, electrical currents) in favor of a classical, or, more precisely, Maimonidean contemplative ideal. The combination of idiomatic good humor, philosophical high seriousness, and literary allusiveness with which Maimon expresses himself is uniquely his own and, in Reitter's careful, felicitous translation, occasionally reminds the modern English reader of no one as much as Saul Bellow, another bumptious Jewish outsider.

In the final sentence quoted above, Maimon writes that "I left my people, my homeland, and my family to seek the truth." As he expected at least a certain kind of reader to recognize, this translates God's call to Abraham - "Go forth from your land, and your birth place and the house of your father" (Genesis 12:1)—from the second person to the first, and so from a command to an act of human autonomy. The allusion, however, is not merely biblical, for Maimon is also drawing upon Maimonides' famous account of Abraham as the first philosopher, whose alienation from his native pagan culture was a prerequisite for true philosophy. ${ }^{24}$ The self-conscious irony, even blasphemy, of the allusion is that Maimon's story was also one of movement in the other direction, away from the faith of Abraham, although it was never really that simple, and Maimon was profoundly aware of this.

In Karl Philipp Moritz's brief editorial introduction to Maimon's autobiography, he wrote that Maimon's story showed how "even in the most oppressive conditions, the capacity to think can develop into a mature human intellect." What gave the book added value, he wrote was

\footnotetext{
${ }^{23}$ See below preface to bk. 2, p. XYZ. \{ ? Page refs needed $\}$

${ }^{24}$ See Maimonides, Guide of the Perplexed, 3:29, especially pp. 516-17, and cf. Maimonides, Mishneh Torah, Laws of Idolaters 1:2.
} 
Its balanced, broad-minded account of Jewry and Judaism, which is in fact the first of its kind. At a time like now, when the educational formation and enlightenment of the Jewish people has become a special topic of reflection, it is a work that warrants close attention..$^{25}$

As we shall see, Maimon's sense of what constituted true educational formation and enlightenment (Bildung und Aufklärung) of the Jewish people or anyone else was substantially different than those of Moritz or Maimon's erstwhile colleagues and benefactors in the Jewish Enlightenment (Haskala). For Maimon, genuine enlightenment consisted entirely in the study of mathematics, the sciences, and serious philosophy. However, the interpretation of Maimon's autobiography as an exemplary tale bearing a cultural moral Maimon himself would not have endorsed was repeated with increasing crudity over the years. Thus, Heinrich Graetz, the leading nineteenth-century historian of Judaism wrote that Maimon was a "striking example" of the Jewish capacity for culture:

He rose from the thickest cloud of Polish ignorance to pure philosophical knowledge, attaining this height by his unaided efforts, but owing to his skepticism, he fell prey to shocking errors. ${ }^{26}$

This is, of course, nonsense, both as literary interpretation and as intellectual history. Maimon was the son of a recognized rabbinic scholar and himself a Talmudic prodigy in a time and place in which such learning held both cultural prestige and tangible rewards. Moreover, when, as an adolescent and young adult, he rejected the Talmudism to which he was heir (and which he regarded as, among other things, a noble form of religious "Stoicism"), Maimon turned to alternative medieval conceptions of Judaism in Kabbalah and Maimonidean rationalism, which were no less rigorous and scholastically complex. Even the Hasidic court of the Maggid of Mezritsh, which he visited as a young man around 1770, was, enthusiastic practices notwithstanding, made up of a cadre of spiritual elitists devoted to a complex and highly original theological tradition. Moreover, the Maimonidean philosophy that was to remain Maimon's polestar throughout his peripatetic life afforded a vision of pure rationalism that was only available to traditional readers of medieval rabbinic texts such as himself. Indeed, as Maimon well knew, even his radicalization of Maimonides had precedents among the medieval Jewish interpreters of his Guide of the Perplexed such as the fourteenth-century Averroist Moses Narboni, whom he quotes in his autobiography on precisely the issue of

\footnotetext{
${ }^{25}$ Moritz, editor's preface, p. X.\{ ? $\sim$ Page ref needed $\}$

${ }^{26}$ Heinrich Graetz, History of the Jews (Philadelphia: Jewish Publication Society, 1956), trans. Bella Löwy and Philipp Bloch, vol. 5, p. 407.
} 
cognitive perfection and whose commentary he had published alongside his own commentary, Giv'at ha-Moreh (1791), which was the first substantial work of modern philosophy written and published in Hebrew.

A feature of Maimonides' philosophy that deeply influenced Maimon is its deep respect for reason. Thus, in summarizing the climactic conclusion of the Guide, Maimon translates and quotes a subtly astonishing passage: ${ }^{27}$

The behavior of a man when he is alone with his family is very different from his behavior when he is in the presence of a great king. Whoever strives for perfection should know that the greatest of all kings, namely, the reason that God has given him, resides within him. ${ }^{28}$

Maimonides would seem to be employing the standard rabbinic admonition that one should regard his stand before God with as much, or more, awe as one would before a flesh-and-blood king. ${ }^{29}$ But, as Maimon noticed, his master had actually given the tradition a radical twist: "the greatest of all kings" here, is not God, but rather, "the reason that God has given man." 30

Maimon's loyalty to this monarch is almost boundless. Thus, he accepts a strong version of the "Principle of Sufficient Reason" (that is, the claim that everything must be rationally explicable, or alternatively, that there are no brute facts). ${ }^{31}$ Thus, in the middle of his explication of Maimonides' Guide, he writes

The world may be, in terms of time, finite or infinite; still, everything in it (as consequences of the highest wisdom) must be explainable through the principle of sufficient reason. How far we can actually get in achieving this is beside the point. Those things that Maimonides, working with the astronomy of his day, regarded as inexplicable, new discoveries (particularly Newton's system) equip us to explain quite well. The highest order in the arrangement of the world's structure is for us a necessary idea of reason, which, through the use of reason with regard to objects of experience, we can approach but never reach. ${ }^{32}$

For Maimon, the "Principle of Sufficient Reason" should govern philosophical inquiry. We clearly do not know the reason for many facts we

${ }^{27}$ Pines 2:629.

${ }^{28}$ Maimon, Autobiography, 2:10, p. XYZ. \{ ? Page ref needed $\}$

${ }^{29}$ See, for example, Mishnah, Avot 3:1.

${ }^{30}$ In the Theological Political Treatise, Spinoza employs similar imagery when speaking of "the majesty of reason" (ch. 15l Geb. 3/188).

31 On the Principle of Sufficient Reason, see Melamed, Yitzhak Y. and Martin Lin, "Principle of Sufficient Reason," Stanford Encyclopedia of Philosophy (Spring 2017 edition), ed. Edward N. Zalta, forthcoming. https://plato.stanford.edu/archives/spr2017/ entries/sufficient-reason/.

32 P. XYZ. Italics added. \{ ? PAGE REF NEEDED $\}$ 
encounter in experience, but we should never stop requiring explanation for facts that appear to be contingent or brute. In the Autobiography, we find Maimon time and again inquiring about the "Grund" (ground or reason) of this or that phenomena, regardless of the field in which it is located.

Let us take Maimon at his word, then, and regard his exposition of Maimonides not as "padding" or an absurdly long learned digression, but rather as the rationalist key with which to interpret several of the most famous and striking episodes of his account of his strivings toward an ideal of enlightenment, or intellectual perfection, for which Maimon left his people, his homeland, and his family.

Although Maimon first left his family in late adolescence, the family in question was already that of his wife and children, the oldest of whom, a boy named David, was a young child. As he recounts to great comic effect, Maimon's recently widowed father had married him off at the age of eleven, as a desirable young Talmudic prodigy. ${ }^{33} \mathrm{~A}$ few years later, Maimon was working as a family tutor in a nearby village when he heard about an exciting new religious sect known as "Hasidim," who practiced a new form of piety. Shortly before he was to return home with his wages, he met a young Hasid, whose account of the new movement was so tantalizing to Maimon that instead of walking the two miles home to his family after he had received his wages he left for the Hasidic court of Rabbi Dov Ber, "the Maggid," in Mezritsh, which took several weeks.

Maimon's chapter on this "secret society," which he described along the lines of the Bavarian Illuminati and Freemasons as the attempt to create a new way of life based upon a genuine "system of perfection," remains one of the most historically valuable and apparently accurate first-person accounts of the early Hasidic movement. ${ }^{34}$ It was also a provocation directed at his contemporary enlightened Jewish readers, who, to say the least, would not have regarded the new movement as having a philosophical basis. Indeed, although Maimon's account is highly

\footnotetext{
${ }^{33}$ For an account that shows how the pattern of Maimon's early life persisted into the nineteenth century, see Imannuel Etkes, "Marriage and Torah Study among Lomdim in Lithuania in the Nineteenth Century," in David Kraemer, ed., The Jewish Family (Oxford: Oxford University Press, 1990), pp. 153-78.

${ }^{34}$ Maimon's account remains a key primary text in the study of early Hasidism. See, for instance, David Assaf, "The Teachings of Dov Ber of Mezrich in Solomon Maimon's Autobiography," Zion 71 [Hebrew], Ariel Mayse, "Beyond the Letters: The Question of Language in the Teachings of Rabbi Dov Baer of Mezritch," (Harvard Dissertation, 2015), and, most recently, Melamed, "Spinozism, Acosmism, Hasidism: A Closed Circle," in Amit Kravitz and Jörg Noller, eds., The Concept of Judaism in German Idealism (Suhrkamp Verlag, 2018).
} 
critical, at one point he calls these enthusiastic Hasidim "enlighteners" (Aufklärer) with generally "accurate ideas of religion and morality.”

They maintained that man achieves his highest perfection only by regarding himself as an organ of God, rather than as a being that exists and acts for itself. The former, they felt, was man's destiny. Thus the proper course of action was not to spend their entire lives apart from the world, trying to suppress their natural feelings and kill off their vital powers. Instead they should develop their natural feelings as much as possible, use their strengths, and constantly try to extend their influence. ${ }^{35}$

This pantheistic, or acosmic, idea was illustrated for Maimon by the enthusiastic young initiate who presented a highly original interpretation of a biblical verse describing the prophet Elisha at the time of prophetic inspiration:

He continued, full of spiritual excitement: "As the player (musician) played, the spirit of God came to him" (2 Kings 3:15). They [the Hasidic teachers] interpret this verse as follows: As long as a person tries to act as an independent being, he will not be able to receive the Holy Spirit. He must act as merely an instrument. Thus the meaning of the passage is: When the player כלי נגנגן the servant of God-becomes identical to the instrument, the Holy Spirit will come to him. ${ }^{36}$

As Maimon explains in a footnote, this is a clever bit of philosophical exegesis because both the act of playing and the musical instrument played upon are designated by the same word, and "the Hebrew character that is used as a prefix can be taken to mean both with and the same." According to this Hasidic homily, one must annul the boundaries of the self as an independent being in order to make oneself an organ of God. Thus, the player, the played, and the act of playing are one and the same, just as the knower, the known, and the knowing, are according to Maimonides.

Nonetheless, after a few weeks in the Maggid's court, Maimon became disillusioned by what he took to be the lack of intellectual seriousness on the part of the Hasidic followers and their political manipulation by the Maggid and his disciples. Yet the idea of a monist, or acosmist, understanding of Maimonides' dictum, in which knower and the known can be identified because they are ultimately aspects of the same single substance, would stay with him.

\footnotetext{
${ }^{35}$ Maimon, ch. 19, p. XY. \{ ? PAGE REF NEEDED\}

${ }^{36}$ On this passage, and Maimon's interesting account of both Hasidism and Kabbalah more generally, see Moshe Idel, Between Hasidism and Magic (State University of New York Press, 1995), especially pp. 196-200.
} 
Years later, after having successfully arrived in Berlin, Maimon discussed Spinoza's controversial monism with Dr. Markus Herz, a leading figure in the Berlin Jewish enlightenment.

I tried to explain Spinoza's system, for instance, and more specifically, that all objects are manifestations of a single substance. He interrupted me: “My God! You and I are different people, aren't we? Doesn't each of us have his own existence?"

"Close the shutters!" I exclaimed in response. He was surprised by this bizarre reaction, until I told him what I meant by it: "Look," I said, "the sun is shining through the windows. The rectangular window creates a rectangle of reflected light and the round window creates a circle. Are they therefore different things, or are they one and the same sunshine? If you close the shutters, all the light will disappear completely." ${ }^{37}$

Seven chapters earlier, in his account of Maimonides' discussion of the triple identity of the knowing subject, the object of knowledge, and the act of knowing, Maimon remarks that the "intelligent reader" will be able "to see where all this is going." 38 What he seems to mean by this is that Maimonidian philosophy taken to its logical conclusion and the kabbalistic core of Hasidism, when purified of its obscure symbolism, both point toward the radical monism of Spinoza. ${ }^{39}$

This idea also seems to lie beneath the surface of Maimon's ambivalent elegy for his "great friend" Moses Mendelssohn, the leading figure of the Jewish Enlightenment (Haskalah). It is clear that Maimon was deeply grateful to Mendelssohn for his intellectual patronage and gentle, considerate manner. Unlike Herz and others, Mendelssohn regarded Maimon as an intellectual peer, not an amusing cultural novelty, a kind of "dog that has learned to say a few words" and is suddenly found to be philosophizing in what Maimon elsewhere describes as "a grammatically deficient mix of Hebrew, Yiddish-German, Polish, and Russian." 40

Mendelssohn had spent the last year of his life defending his friend, the late Gotthold Ephraim Lessing, against the charge of Spinozism, a charge

${ }^{37}$ Maimon, bk. 2, ch. 11, p. XY. \{ ? Page refs needed\}For the identification of his interlocutor as Markus Herz, see Martin L. Davies, Identity or History: Marcus Herz and the End of the Enlightenment (Detroit: Wayne State University Press, 1995), p. 10n28. For an exposition of Maimon's unique reading of Spinoza, see Yitzhak Y. Melamed, "Salomon Maimon and the Rise of Spinozism in German Idealism," Journal of the History of Philosophy 42, no. 1 (2004), pp. 67-96.

${ }^{38}$ Bk. 2, ch. 4, p. XYZ. \{ ? P Page refs needed $\}$

${ }^{39}$ For Spinoza's own discussion of the Maimonidean doctrine of the identity of knowing subject, the act of knowing, and the known object, see Spinoza, Ethics, pt. 2, proposition 7, scholium.

${ }^{40}$ Maimon, bk. 2, ch. 11, p. XY; bk. 1, ch. 21. \{ ? P Page ref needed $\}$ 
that was widely taken to undermine the possibility of a moderately religious, politically non-radical, Enlightenment. Writing seven years later, Maimon rejected Jakobi's controversial attack on Mendelssohn and Lessing, but then went on to argue that Mendelssohn himself had not really been very far from Spinoza's pantheism. Of Mendelssohn's rejection of Spinoza in favor of the Leibnizian system of Christian Wolff, Maimon wrote:

The only way I could understand Mendelssohn's and the Wolffians' attachment to their system was by seeing it as a political trick and as an act of hypocrisy, through which they assiduously tried to approximate the thinking of the common man. . . . Mendelssohn . . . didn't want to block my drive to explore; in fact, he secretly rather liked it, and he said that even though I was on the wrong path at the moment, I should not curtail my thinking. ${ }^{41}$

From his close reading of Maimonides, his medieval interpreters, Spinoza, and his own personal experience, Maimon was always very sensitive to the connections between politics and theology. Indeed, he described the first chapter of his Maimonidean synopsis as "Theologica Politica," perhaps the first description of political theology as an intellectual field or literary genre.

Later, when Maimon's erstwhile patrons, men like Markus Herz who represented the commonly accepted versions of Jewish Bildung and Aufklärung, complained of Maimon's vocational aimlessness (though he had studied pharmacology and medicine for three years, he had no interest in becoming a pharmacist or physician), his willingness to spread "harmful ideas and philosophical systems," and his dissolute life (he coyly admits in this chapter to having frequented brothels), Mendelssohn rebuked him. But, at least in retrospect, Maimon would have none of it.

I countered the first reproach by reminding him that from the very beginning, I had explained to my friends that my special upbringing had left me uninterested in practical undertakings and made me prefer the quiet, contemplative life. . . . "As to the second point," I continued, "my opinions and philosophical systems are either true or false. . . . Yet it isn't the harmful character of my views that has led these men to turn against me; rather, it's their inability to understand my ideas and their desire to avoid the humiliation of admitting this. As to the third reproach, I say to you, Herr Mendelssohn, nothing less than: We are all Epicureans. ${ }^{42}$

This is another one of those deceptively simple passages in which Maimon is actually doing a great deal. In the first place, while it might be odd to write

\footnotetext{
${ }^{41}$ Maimon, bk. 2, ch. 11, p. XYZ. \{ ? Page ref needed $\}$

${ }^{42}$ Maimon, bk. 2, ch. 13, p. XYZ. \{ ? Page ref needed $\}$
} 
of oneself in the very same chapter both that one frequents brothels and that one prefers a "quiet, contemplative life" (italics very much Maimon's), he is making, yet again, his Maimonian (if not quite Maimonidean) point about the real nature of knowledge, and its distance from the instrumental reason and fashionable chatter of most of his "enlightened" contemporaries. Finally, when Maimon tells Mendelssohn that "we are all Epicureans," his German readers no doubt took him as merely making the point that the conduct of one's life is ultimately a matter of taste and subjective desire. Of course, the term "Epicurean" was, like "Spinozist," a term of learned abuse in the seventeenth and eighteenth centuries, but Maimon meant something much more aggressive, with a real idiomatic punch. For in both rabbinic Hebrew and Yiddish, the word Epicurean, or apiqores, is the standard (and derisive) term for heretic. Thus, if we translate Maimon's sentence into the only language that he and Mendelssohn fully shared, it becomes not merely a statement of moral hedonism, but a bold (and perhaps pained) admission and accusation. This accusation becomes even sharper when we note that Maimon has just criticized Mendelssohn for inconsistency in his famous opposition to the practice of excommunication. If a Jew is duty-bound to follow the laws of his religion, as Mendelssohn held, then, Maimon argued, the religious authorities must have the power to enforce that obligation. Maimon accepted this authority but rejected the proposition that Jews were obligated to remain in their community, that is to remain Jewish. The irony, of course, was that, in this very conversation, Mendelssohn was, in essence, banishing Maimon from Berlin in an act of quasi-rabbinic, or at least Jewish communal, authority.

Maimon's life, or at least his life as he recounts it, was full of confrontations, more than a dozen of which are recounted over the course of the Autobiography. Although Maimon generally gets the last word in these episodes, like Rousseau to whom he occasionally alludes, he was not averse to showing himself in an unflattering light. One of the most famous of these confrontations occurs after he sends a comical letter to a Lutheran pastor. The letter re-envisions the story of his life as one of progressive enlightenment leading inexorably to conversion to Christianity, but only as-to quote the poet Heine a half-century later-an entry ticket into European culture. ${ }^{43}$

I was born in Poland, Jewish. Brought up and trained to be a rabbi, I saw some light in the blackest darkness, which moved me to pursue light and truth, and try to free myself from superstition and ignorance. Because it was impossible to work toward my goal in the land where I was born, I moved to

${ }^{43}$ Hugo Bieber, Heinrich Heine: A Biographical Anthology, trans. Moses Hadas (Philadelphia: Jewish Publication Society, 1956), p. 196. 
Berlin. Supported by some enlightened men of my nation, I studied therenot systematically, but rather simply to satisfy my desire for knowledge. But because our nation has no use for such desultory study, these men naturally grew weary of supporting me, and they declared their support pointless. Thus, for the sake of both earthly and eternal happiness [ewige Glückseligkeit], which depends on the attainment of perfection [Erlangung der Volkommenheit], and also as a way of becoming useful to both myself and others, I have decided to accept the Christian religion. Admittedly, the articles of faith in Judaism come closer to reason than those in Christianity, but with respect to its practical application, the latter has the advantage over the former. And since morality, the chief aim of all religions, consists of actions rather than beliefs, Christianity is thus closer to this aim than Judaism. Furthermore, I hold the mysteries of Christianity to be what they are, mysteries: allegorical representations of the truths that matter most to humanity. In this way, I can reconcile my belief in the mysteries with reason, although I cannot believe in them as they are commonly construed. I ask, then, with all due deference: After giving such a confessional statement, am I worthy or unworthy of the Christian religion? ${ }^{44}$

The pastor finds Maimon to be "too much of a philosopher to be a Christian," which is, perhaps, more precisely true than he knows (though, of course, it is Maimon who wrote this dialogue). For, his plangent, chutzpadik self-dramatization notwithstanding, Maimon was drawing upon precise doctrines in Maimonides' philosophy of religion, which he had summarized only a few chapters earlier: Religious law is instrumental and its ultimate goal is the attainment of intellectual perfection, which is the true understanding of the universe and consequent worship of its creator resulting in "eternal happiness." However, such an achievement is only possible for a healthy individual living in a well-ordered society. Religious beliefs are thus valid to the extent that they approximate metaphysical truths or are conducive to the governance of that society. ${ }^{45}$ As Maimon writes near the outset of his commentary to Maimonides' Guide, Giva't ha-Moreh, which he had published only two years earlier, "know that the true good is the acquisition of perfection [kinyan hashelemut] ... and whatever other thing is a means to this acquisition of perfection is good in relation to it." 46 Thus, if one needs to be a Christian

${ }^{44}$ Maimon, bk. 2, ch. 14.

${ }^{45}$ See, especially, Maimon, bk. 2, chs. 9 and 10, summarizing Maimonides, Guide of the Perplexed, 3:25-34 and 3:51-54.

${ }^{46}$ Maimon, Giv'at ha-Moreh, S. H. Bergmann and Natan Rotenstreich, eds. (Jerusalem: Israel Academy of the Sciences and Humanities), p. 35, commentary to Maimonides, Guide 1:2. (Italics mine.) 
to flourish intellectually in Germany in the 1780s, then Christianity ison this radical reading of Maimonides-better than Judaism in "practical application," as long as one does not have to commit to articles of faith that violate reason. ${ }^{47}$

It should be noted that although Maimon was, here as elsewhere, selfconsciously making an argument that he did not expect his interlocutor to fully understand, his offer to convert did have a specific sociohistorical context. Rumors that Mendelssohn himself might accept some such Arian or Socinian version of enlightened Christianity had swirled about Enlightenment circles for almost two decades. Nor was Maimon's offer to convert to a demystified Christianity the last of its kind in eighteenthcentury Germany. In 1799, David Friedlander (a disciple of Mendelssohn and a patron of Maimon) famously made a somewhat similar offer to the liberal Protestant pastor Wilhelm Abraham Teller on behalf of some of the leading Jewish families of Berlin, though their aspirations were decidedly more social than metaphysical. ${ }^{48}$

Maimon presumably had the same radical argument in mind when he was later summoned by Raphael Kohen, the Chief Rabbi of Altona, Hamburg, and Wandsbeck, who confronted him about having abandoned his wife and family, as well as traditional Judaism:

He received me with a great show of respect. When I told him about my childhood and family in Poland, he began to wail out lamentations, wringing his hands: "Oh! Can it be that you are the famous Rabbi Joshua's son? I know your father very well. He is a pious and learned man. And I know you, too. I tested you on a number of occasions when you were a boy, and I found you so full of promise. Oh! How is it possible that you have changed so much!" (Here he pointed to my shaved beard). I replied that I felt honored to know him-I remembered his examinations well.

\footnotetext{
${ }^{47}$ The medieval Averroist commentator whose commentary to the first part of the Guide Maimon chose to publish alongside his own, Moses Narboni, hints at the validity of such an argument albeit only in the face of medieval martyrdom, not modern discrimination. See the discussion of Bernard Septimus, Narboni, and Shem Tov on martyrdom in Isidore Twersky ed., Studies in Medieval Jewish History and Literature, vol. 2, pp. 447-55, concentrating on the commentary to Guide 3:11 and 3:34.

${ }^{48}$ Interestingly, Maimon seems to set his account of his encounter with the Lutheran pastor at roughly the same time as Mendelssohn's Jerusalem controversy in 1783. For David Friedlander's offer, see Friedlander, Sendschreiben an seine Hochwürdigne, Herrn Oberconsistorialrat und Probst Teller zu Berlin, von einigen Hausvaetern jüdischer Religion (Berlin, 1799), partially translated in Paul Mendes-Flohr and Jehuda Reinharz, The Jew in the Modern World, op. cit., pp. 115-20. On this historical episode and its repercussions, see the classic discussion of Michael Meyer, The Origins of the Modern Jew: Jewish Identity and European Culture in Germany, 1749-1824 (Detroit: Wayne State University Press, 1979).
} 
My actions, I maintained, had no more run counter to religion (properly understood) than to reason. ${ }^{49}$

Later still in Breslau, when his wife and now-adolescent son David arrive to force him to return home or finally grant her a divorce, Maimon describes teaching his son some passages from the Guide of the Perplexed, and trying "to show him that enlightening the mind and reforming religious customs would bring much more good than bad."

Maimon also attempts to use his wife's demand to raise several hundred thalers from his patrons, ostensibly in order to return to Poland in a position to be financially independent from his traditionalist relatives and their community. Early in the Autobiography, Maimon had written that "the majority of Polish Jews are scholars, that is to say devotees of idleness and contemplation (every Polish-Jewish boy except the most obviously incapable is raised to become a rabbi)." 50 Of course, this wasn't really true-or rather it was only true of the elite rabbinic class into which Maimon had been born-but, despite the derisiveness of his characterization, it is clear that Maimon never moved beyond the idea that someone should support him, so that he could remain in "idle contemplation," of one kind or another. ${ }^{51}$ Thus, in an earlier chapter, he reports that "the happiest and most successful period in my life" was when, after already having abandoned his family, he was supported by the Rabbi and Jewish community of Posen as a distinguished scholar. If he really was considering return to Poland with his wife and son, perhaps this was what Maimon had in mind, though it is unlikely that a few hundred thalers would have sufficed. In the end, he raised enough to give his wife a modest settlement and granted her the divorce she had been awaiting for more than a decade. Here, perhaps, is the place to note that in this account, and elsewhere in the Autobiography, there is a persistent note of misogyny. ${ }^{52}$

\footnotetext{
${ }^{49}$ Maimon, bk. 2, ch. 14. Maimon does not name Kohen in this passage but expects that at least many of his Jewish readers will recognize him as a leading rabbinic opponent of the Jewish Enlightenment.

${ }^{50}$ Maimon, bk. 1, ch. 19. The Babylonian Talmud (Sanhedrin 17b and Megilah 3b) stipulates that a scholar is not allowed to live in a town that has less than ten batlonim (literally idlers, i.e., scholars whose only vocation is study and whose living is paid by the community).

${ }^{51}$ For the demographic realities with regard to the number of Talmudic scholars on the Polish-Lithuanian ground see Shaul Stampfer, Lithuanian Yeshivas of the Nineteenth Century: Creating a Tradition of Learning (London: Littman, 2014).

${ }^{52}$ Thus, Maimon only mentions the beauty of two women, his late mother and his wife, but both only in the context of their being the objects of sexual desire by non-Jews. See also Maimon, bk. 2, ch. 13, in which "a foolish old woman falls in love with me," pp. XYZ. \{ ? PAGE REF NEEDED\}He does, however, censure the misogyny he allegedly observed among Hasidim at Mezritsh, on which see below, ch. 19, p XYZ and 115n. \{ ? PAGE REF NEEDED\}
} 
The act of ending an autobiography almost inevitably stands as a kind of narrative surrogate for the death of its subject, which the author cannot possibly describe. The desire for intellectual perfection that underlies Maimon's autobiography was also understood to be a drive toward death in the medieval philosophical and mystical traditions that he drew upon. Conjunction with or cleaving (devequt) to either the active intellect of Maimonidean philosophy or the Shekhina of the Kabbala was represented as a kind of prophetic rapture and tied in the exegetical tradition to the "kiss of God," by which Moses and his siblings were said to have died. ${ }^{53}$

Maimon understood his life to be a search for intellectual perfection, and yet he told it as a comical story of social frustration. In at least some of his philosophical writings, he similarly described the act of cognition as the impossible attempt of the human, finite intellect to grasp its object in the way that the divine, infinite intellect does. Maimon dedicates the final chapter of the Autobiography, which like the chapters on Maimonides, has never been previously translated into English to "those readers who were bored by my earnest account of the More Newochim." It is a bizarre allegory called "The Merry Masquerade Ball," which brings together Maimon's deep engagement with Maimonidean philosophy, Kabbala, the European tradition of the Goddess Natura, Kant's “Copernican revolution," and his own ambivalence about ever truly fitting into enlightened society. Maimon's fable begins as follows:

One day, in . . . , a ball was held to honor a famous woman. Although no one had actually seen this woman, she was reputed to be of exceptional beauty, but also extremely difficult. She was like a will-o'-the-wisp; the more one thinks oneself to be nearing her favor, the farther away from it one finds oneself. And as soon as one believes one possesses it fully, it vanishes completely. Her name, which should uttered in a respectful tone, is Madame M . . . or, to say the same thing another way, the chambermaid Ph's lady. Because she is, as mentioned, invisible, we know of her beauty only by what comes from the mouth of her gossipy maid, and we can call her by no other name.

All the cavaliers gathered at the ball jostled for the honor of dancing with this lovely woman. Her taste wasn't known, so in an attempt to please her, all kinds of dances were tried out.

As Maimon informs the reader in the first three of twenty-five playful footnotes, this is an allegory of the history of philosophy, the divine Madame M. is Madame Metaphysics, and her chambermaid is Physics. The

\footnotetext{
${ }^{53}$ For Maimonides' discussion of the deaths of Moses, Miriam, and Aaron, see Guide of the Perplexed, 3:51.
} 
allegory is, at the most obvious level, about the pursuit of what is behind mere appearances; the impenetrable thing-in-itself is personified as the elusive Madame Metaphysics who is only known through the chattering of her chambermaid. The dancers and the dances each represent, respectively, schools and arguments in the history of philosophy. ${ }^{54}$

At the end of the exposition of The Guide of the Perplexed with which he prefaced the second part of his autobiography, Maimon had quickly unpacked the famous parable of the king and his palace, which Maimonides had written as "a kind of conclusion," to the work as a whole, as an account of human perfection. A successful dance with Madame Metaphysics would, apparently, be something like speaking face-to-face with Maimonides' king. Maimon also almost certainly had in mind the famous parable from the classic work of medieval Kabbala, the Zohar, which tells of "a beautiful young maiden upon whom no one has set eyes," and her secret lover who must penetrate her veils and riddles until he is "a perfect human being, a true husband of Torah, for to him she has uncovered all her mysteries, holding back nothing." 55 Finally, in his earlier chapter on the "secrets of religion," Maimon had compared the famous inscription on the pyramid of Sais, "I am all that is, was, and will be; no mortal has lifted my veil," with the biblical God's self-description to Moses, both of which, to Maimon, meant "nothing other than that there was a single "immediate cause of all Being'." 56 Only a few years earlier, in his Critique of Judgment (1790), Kant had written that this was "the most sublime thing ever said." 57

After some characteristic Maimonian slapstick-Monsieur Ph. (Pythagoras) insisted that everyone "dance with ruler, triangle, and compass in hand"; Monsieur Pl. (Plato) insisted that "it was impossible to win the honored lady's favor if one didn't keep one's eyes on certain images floating around the hall (which no one other than him could see)"; Monsieur L. (Luecippus, a materialist) "gave up on the storied lady" and danced with the chambermaid, and so on-Kant arrives on the scene.

One of the most intelligent of them couldn't stand this quixotic behavior any longer. He remarked that the honored lady was a child of the imagination, whose image could spur a knight to acts of heroism, but could also, if unchecked by caution, prompt all kinds of excess. He demonstrated how

\footnotetext{
${ }^{54}$ This chapter should be compared to Maimon's sketch of the history of philosophy in his introduction to Giv'at ha-Moreh.

${ }^{55}$ For the parable of the ulimta shapirta ve-leit lah einayin (literally "the beautiful maiden without eyes"), see Zohar 2:99b (Mishpatim).

${ }^{56}$ Maimon, bk. 1, ch. 20, p. XY, and see the notes there. \{ ? PAGE REF NEEDED\}

${ }^{57}$ Critique of Judgment, sec. 49.
} 
the illusion came to be and how one could save oneself from the threat it posed. This garnered a great deal of attention. Parties formed. Some stubbornly tried to assert the existence of the woman, which up to now had been taken for granted. Others questioned their assertions.

It is at this point that Maimon's "friend," who he coyly declines to identify in the accompanying footnote, arrives: "Not only did he support the theory of the lady's nonexistence, he also claimed that it was possible to be a good cavalier without believing in such a figment of the imagination." 58

An elaborate costume ball given at an intellectual salon was just the kind of social expression of enlightened society in which Maimon was incapable of participating gracefully. He was chronically unkempt, often drunk, and continued to speak German with a pronounced Yiddish accent while gesturing like a Lithuanian Talmudist (his friend Sabbattia Wolff fondly recalled him swaying and chanting over a mathematical treatise by Euler). ${ }^{59}$ Even his German philosophical prose was constantly veering into a kind of rabbinic commentary or even metacommentary. So there is, perhaps, a poignancy on the surface of this allegory that reinforces its moral: the modern aspiration for metaphysical truth, to dance with Madame Metaphysics, is no less naive than the desire to conjoin with the Aristotelian active intellect or cleave to the Shekhina of the Kabbalists. However, the final lines of Maimon's autobiography decline even that much narrative closure: "I wonder how this strange masquerade ball ended."

In 1795, Maimon found his last patron, a free-thinking count named Adolf Kalkreuth, who invited him to his Berlin residence, and, later, to move to his estate in Lower Silesia, where Maimon stayed for the rest of his life. This was probably the longest period in his adult life in which he stayed in one place, and accounts differ as to how he spent the time. Some depict him as living in a drunken stupor, his main companion a dog who Maimon claimed was, like him, a philosophical eclectic and to whom he promised to leave his library. ${ }^{60}$ On the other hand, he published his last major work, Kritische Untersuchungen über den menschlichen Geist (1797) in these years, and kept up an active philosophical correspondence until the end of his life.

In the final weeks of his life, he was visited by an earnest local Protestant clergyman named J. C. Tscheggey, who published a memoir of their conversations about philosophy, religion, and the possibility of

${ }^{58}$ Maimon, bk. 2, ch. 16, p. XYZ. \{ ? PAGE REF NEEDED\}

${ }^{59}$ Wolff, Maimoniana, p. 89.

${ }^{60}$ Noah Jacobs, "Solomon Maimon's Life and Philosophy," Studies in Bibliography and Booklore, vol. 4, no. 2 (1959), p. 60. 
an afterlife. When Tscheggey urged him that his spirit would live on, Maimon replied that, he could go a good way with "faith and hope ... but what does that help us?" It helps, replied the pastor, "at least to peace." Maimon replied "I am at peace," and died on November 22, $1800 .{ }^{61}$

His body was delivered to the nearby Jewish community of Glogau. He was, according to a local tradition, buried as a heretic outside the cemetery in an unmarked grave. Children are said to have been encouraged to throw stones at the coffin while shouting "apiqores!" When Count Kalkreuth inquired about the funeral, he was, by one account, told that Maimon had been buried in a special area marked traditionally for philosophers, a bitter jibe Maimon himself might have appreciated. ${ }^{62}$ Count Kalkreuth was not satisfied and apparently had a memorial stone erected in his honor. ${ }^{63}$ Maimon's friends, Lazarus Ben-David and Sabbattia Wolff, wrote memoirs, and his philosophical work is of permanent value, but Maimon has been remembered largely because of his own "wonderful piece of autobiography." 64

Finally, a few words are in order about how we have edited and annotated Maimon's text. As noted above, previous editions and translations of Maimon's Lebensgeschichte treated it with a fair measure of paternalism, even disrespect, deleting parts of the text and appendicizing others. The present English text is a translation of the original edition as published in 1792 and 1793 (the original page numbers are inserted in square brackets in the body of the text).

Whenever Maimon quotes a non-German text-generally a Hebrew or Latin phrase-we have retained the original language in the text and provided the translation in a note. We have also retained Maimon's nonstandard transliteration of Hebrew words (adding explanatory notes where necessary) to preserve these bits of eighteenth-century Ashkenazi Hebrew dialect.

${ }^{61}$ P. Tscheggey “Über Salomon Maimon und seine letzten Stunden,” Kronos einem Archiv der Zeit (1801), pp. 20-46, reprinted in Wolff, Maimoniana, and adapted by Herbert Friedenthal in a curious work, The Everlasting Nay (London, 1944).

${ }^{62}$ For accounts of the funeral, see Simon Bernfeld, Michael Sacks (Berlin, 1900), p. 3; Jakob Fromer ed., Salomon Maimons Lebensgeschichte, pp. 35-40; Noah Jacobs, "Salomon Maimon's Life."

63 The sandstone neoclassical memorial destroyed during World War II and reconstructed in 2013. See D. Brylla, "Salomon Maimon has a Memorial," Philosophia (2014) vol. 42, pp. 593-95.

${ }^{64}$ For a concise, penetrating account of Maimon as a thinker, see the afterword to this volume by Gideon Freudenthal. For a penetrating discussion of his place in the generation of philosophers who followed Kant, see Paul Franks, All or Nothing: Systematicity, Transcendental Arguments, and Skepticism in German Idealism (Cambridge: Harvard University Press, 2005). 
Maimon's own occasional footnotes to his text are reproduced on the same page and are easily distinguishable from our editorial notes. Occasionally, Maimon ends paragraphs addressing sensitive matters with a hyphen, a practice similar, though not identical, to our ellipsis, apparently indicating to the reader that he must pass in silence over some issues. We preserved this use of the hyphen in our edition.

As discussed, Maimon's writing is rich in references and allusions, both playful and serious, to other works. His sense of himself as an interloper in German and Enlightenment letters who had to prove himself together with the common Rabbinic practice of weaving a new text out of quotations combined to create a unique literary tapestry. We have identified many of Maimon's sources and allusions, but our aim throughout has been to create a useful reading edition for students and scholars working in English-not a critical edition of the text, an exhaustive commentary upon it, or a comprehensive review of the secondary literature upon which we have drawn. In citing secondary work, we have generally preferred recent work in English, since this edition is primarily for an English-reading audience, however these studies will quickly lead the interested reader into the secondary literature, and a more comprehensive bibliography is provided at the end of the book. It is our hope that this edition, together with other recent scholarship on Maimon, will inspire further work on, and translations of, Maimon's brilliant body of work, as well as his somewhat brief and wholly extraordinary life. 



\title{
EDITOR'S PREFACE
}

\author{
Karl Phillipp Moritz
}

IT SHOULDN'T BE NECESSARY TO SELL readers on the autobiography that follows. The book tells of how, even in the most oppressive conditions, the capacity to think can develop into a mature human intellect, and also of how the true drive for knowledge won't be daunted by obstacles that seem insurmountable. Whoever finds such things compelling will be drawn in.

What gives the book additional value is its balanced, broad-minded account of Jewry and Judaism, which is in fact the first of its kind. At a time like now, when the cultural education and enlightenment of the Jewish people has become a special topic of reflection, it is a work that warrants close attention.

Depicted in a true and unsparing light are the consequences of ignorance in a land roiled by its taking the first steps toward true culture. Indeed, the facts that one reads here may do more good than an extensive treatise on this matter.

The author's story will allow the reader to experience the place where-and the people among whom-he happened to be born, and where reason enabled his mind to reach a state of development that created intellectual needs that could only be met elsewhere, forcing him to leave.

And it is certainly remarkable how intellectual needs can intensify to the point where material lack and even the most extreme scarcity that the body can bear mean little, as long as those needs are met.

Such episodes are important not only for the particular fate of a single individual, but also because they shed light on the dignity of human nature and should inspire our reason to be confident in its powers as it strives upward. 

THE

AUTOBIOGRAPHY

OF

SOLOMON

MAIMON 



\section{Introduction}

The population of Poland can be divided into the following six classes or estates : high nobility, lower nobility, half nobility, burghers, peasants, and Jews. ${ }^{1}$

The high nobility is made up of large landowners and the administrators who hold the high government office. The lower nobility have the right to own land and to occupy any government office, but their extreme poverty keeps them from acting on those rights. The half nobleman is permitted neither to own land independently nor to hold a high government office-this is what distinguishes him from the regular nobility. The half nobleman does occasionally possess an estate, but even so he remains, to some degree, a tenant of the high nobleman in whose territory his estate lies: The half nobleman [2] must pay the high nobleman a yearly tribute for his land.

It is actually the burghers who are the most miserable of all. Of course, the burgher is no serf. He has various privileges, and burghers can even enjoy juridical autonomy. But because the burgher has no profitable land, for the most part, and because he tends not to devote himself seriously to any profession, he lives in the most pitiful state of impoverishment.

The classes of most use to the country are the last two, namely, the peasants and the Jews. The peasants work at plowing fields, herding cattle, beekeeping, etc.-in short, tending to whatever the land produces. Members of the latter class are merchants, bakers, brewers, professionals, craftsmen; they sell beer, spirits, mead, and other such things. They are also the only ones who lease land in the villages and towns, except for on the monastery estates, where Their Reverences believe it is a sin to help a Jew make a living, and thus they let their estates out to peasants, even though they pay a price for doing so. Because the peasants lack the right skills to manage the estates well, the estates fall apart, [3] something Their Reverences opt to endure with Christian patience.

At the end of the last century, estates declined in value so much due to the landowners' ignorance, their oppressive treatment of their tenants, and a widespread absence of economic planning, that land which would yield a thousand Polish guilders today might have been leased to a Jew for ten guilders. Because of his even greater backwardness and indolence,

\footnotetext{
${ }^{1}$ This chapter was composed during what turned out to be the last years of the PolishLithuanian Commonwealth, which dissolved in stages and entirely ceased to exist by 1795 .
} 
the Jew, for his part, wouldn't even have been able to make a living from the land. It was a single development that turned this situation around. Using the name Dersawzes, or general leaseholder, two brothers from Galicia, where Jews are much shrewder than they are in Lithuania, managed to lease-and to rent out to others-all of Prince Radziwil's estates. By bringing about an extraordinarily high level of productivity, the brothers not only improved the estates' economic condition, but they also made themselves rich. ${ }^{2}$

Unfazed by the uproar they caused among their fellow Jews, the brothers raised rents and were as strict as can be in collecting money from their subleaseholders. In addition, they kept [4] a close eye on the lands under their control. Whenever they found a leaseholder who was not managing his estate diligently and industriously-not serving himself and the landowner well but instead idling away whole days atop a warm stove, drunk on spirits-they would summon that person and rid him of his lethargy with a whip. This practice earned the landlords the name of "Tyrants" among their people.

Yet they had a very positive effect. The leaseholder who had always wound up in chains, as a result of not having his ten guilders of lease money on time, now had so much incentive to work hard that he could not only feed his family from the land he leased, he could also pay much more than just ten guilders: four to five hundred guilders, even a thousand.

The Jews can be divided into three categories: uneducated working people, professional scholars, and those who devote themselves [5] to scholarship without concerning themselves with earning a living, relying instead on the first class of people to support them. Head rabbis, judges, school directors, and such types belong to the second category. The third one is made up of scholars whose superior talent and knowledge the uneducated admire so much that they take the scholars into their homes, give them their daughters to marry, and, for years and at their own great expense, provide for both the scholars and the scholars' wives and children. Later on, however, it falls to the wives to support both these sacred sloths and their offspring, who tend to be quite numerous. The wives, understandably, take great pride in this.

Poland may be the only country where you will find religious freedom and religious hatred coexisting in equal measure. Jews there are completely free to practice their religion and enjoy all other civic freedoms. They even have the right to administer their own laws. On the other hand, religious hatred runs so deep that the very name "Jew" elicits disgust. The roots of

\footnotetext{
${ }^{2}$ These brothers were Shmuel and Gedaliah Ickowicz. See Gershon D. Hundert, Jews in Poland-Lithuania: A Genealogy of Modernity (Berkeley and Los Angeles: University of California Press, 2006), pp. 43-44.
} 
this disgust reach back to barbaric times, and [6] have continued to have practical effects down to my own days in Poland, just thirteen years ago.

This apparent contradiction is resolved when we realize that, first, the Jews' religious and civic freedom in Poland does not stem from respect for the basic rights of all mankind; second, religious hatred and persecution are not the results of a conscious policy of weeding out whatever might be detrimental to the nation's moral and material wellbeing. Rather, both things - the Jews' freedom and the animus toward them-are due to the political ignorance and backwardness prevailing in the country. For all the Jews' faults, hardly anyone else in Poland is at all industrious, so the Polish nation had to grant Jews every possible freedom as a matter of practical necessity. At the same time, Poland's moral ignorance and backwardness inevitably lead to religious hatred and persecution. [7] 


\section{My Grandfather's Household}

My GRANDFATHer Heimann Joseph leased several villages near the city of Mirz, in Prince Radziwil's territory. ${ }^{1}$ He chose one of those villages as his base: Sukowiborg, as it was called, on the Niemen River. In addition to a few farmhouses, Sukowiborg had a mill and also a small harbor and cargo depot for ships sailing from Königsberg to Prussia. All this, along with two bridges-one behind the village and a drawbridge on the other side of the Niemen - was included in the lease, which, back then, was worth about a thousand guilders. This was my grandfather's chasaka $a^{(\mathrm{a})}$. Because of the depot [8] and the heavy traffic, the lease should have been very profitable, and with enough energy and economic know-how, my grandfather would have been able (si mens non laeva fuisset) ${ }^{2}$ not only to feed his family but also to amass considerable wealth. However, the poor condition of the estate and the unfavorable political circumstances, as well as my grandfather's total lack of knowledge about how to use the land effectively, proved to be fatal liabilities.

My grandfather installed his brothers as subleaseholders in the villages under his lease. Not only did his brothers arrange to live with him (under the pretext of wanting to be on hand to assist him in his various undertakings), but at the end of the year, they also tried to avoid paying him any rent.

The buildings included in my grandfather's lease had become run down from old age, and they needed to be fixed. The harbors and bridges, too, had fallen into disrepair. According to the lease agreement, the estate

${ }^{1}$ Prince Karol Stanislaw Radziwill (1734-90) was the wealthiest magnate in Poland and a leading figure in the Polish-Lithuanian Commonwealth. Mirz, or Mir, is now in Belarus. On the economic arrangement Maimon describes, see M. J. Rosman, The Lord's Jews: Jewish-Magnate Relations in the Polish-Lithuanian Commonwealth during the Eighteenth Century (Harvard University Center for Jewish Studies, 1990), and, more recently, Adam Teller, Money Power, and Influence in Eighteenth Century Lithuania: The Jews on the Radziwill Estates (Stanford University Press, 2016). Maimon is far from alone in depicting Prince Radziwill as a violent drunkard.

a [Maimon] This term will be explained below.

2 "If our judgment had not been clouded," Virgil, Aenid, bk. 2, the first of Maimon's many classical references, on which, see the introduction. 
owner was responsible for making all necessary improvements and keeping everything in working order. But the owner, like all Polish [9] magnates, spent his time in Warsaw and was unable to oversee renovations on his estate. His estate administrators, for their part, were far more concerned with bettering their own condition than with that of the estates. Indeed, they subjected the tenants to all manner of coercion, ignored orders to carry out renovations, and spent the money intended for improvements on themselves. My grandfather tried almost daily to reason with the administrators, impressing upon them that he couldn't possibly pay his rent if they didn't uphold their end of the contract. But it did no good. All sorts of promises were made, not one of them ever fulfilled. The result was not only the deterioration of the property, but many related misfortunes as well.

Because, as I mentioned, quite a bit of traffic passed through the village, and the bridges were in bad shape, it often happened that just as a Polish lord [10] and his wealthy entourage were crossing a bridge, it collapsed, plunging both steed and rider into the bog. In such cases, the poor leaseholder was immediately summoned, made to lie down next to the bridge, and beaten until the lord felt sufficiently avenged.

My grandfather therefore did everything he could to prevent such an evil turn from happening in the future. He ordered one of his house servants to constantly stand watch at the bridge, so that if a lord had an accident of the kind just described, the sentry could dash off and bring word of the incident to my grandfather's house, leaving my grandfather and his whole family enough time to escape into the nearby woods. They would all run out of the house, utterly terrified, and often spend the night under the open sky, until one by one they dared to go home.

This arrangement persisted through several generations. My father used to tell a story [11] about a similar incident that took place when he was about eight. The whole family had fled to its usual place of refuge, but my father remained in the house by himself: He had been playing behind the oven, unaware of what was going on. The irate lord, arriving with his entourage, found no one on whom he could take out his wrath, so he had every corner of the premises searched and discovered my father behind the oven. The lord invited him to have a drink of brandy. When my father declined the offer, the lord bellowed at him: "If you don't want any brandy, you'll drink water!" He immediately ordered a bucket of water to be brought, and, using a whip, forced my father to drink until the bucket was completely empty. This treatment naturally resulted in a bout of quartan fever that lasted almost a whole year and ruined my father's health. ${ }^{3}$

\footnotetext{
${ }^{3}$ A form of malaria in which the patient's fever tends to spike at three-day intervals (i.e., on the fourth day).
} 
I had a similar experience when I was three years old. Everyone in my family ran out of the house, including the servant carrying me [12] in her arms. With the servants of the approaching lord chasing after her, our servant began to run even faster, and in her great haste she dropped me. I lay in some bushes whimpering until I had the good fortune to be picked up by a passerby - a peasant-who took me home with him. Only after things had quieted down again, and my family had returned home, did the servant remember that she had lost me while fleeing. She started to wail lamentations and wring her hands. They searched for me everywhere, but they couldn't find me, until finally the peasant from the village brought me back to my parents.

Terror and dismay were not all that one experienced during these escapes; there was also the plundering of one's house. The pillagers drank as much beer, brandy, and mead as they pleased, sometimes going so far as to empty whole barrels, make off with grain and chickens, etc. [13]

If my grandfather had simply accepted the injustice and repaired the bridge at his own expense, instead of trying to argue with a more powerful person, he would have avoided all this suffering. But he kept invoking his contract, while the estate administrator only laughed at his misery.

Now a few words about how my grandfather ran his household. His style of living was very simple. The harvest from the fields, along with the yield from the kitchen gardens and the meadows on the land he leased, not only provided his family with ample nourishment, it also sufficed for brewing and distilling spirits. Moreover, my grandfather was able to sell large amounts of hay and grain every year. His beekeeping brought enough honey to brew mead. He also had a lot of cattle.

His family mainly ate an awful-tasting cornbread with bran mixed into it, flour-and-milk gruel, and vegetables grown in the garden. Meat was rare. Their clothes were poor-quality linen and rough cloth. Only the women sometimes made small exceptions, and my father, too, a [14] scholar who craved a different way of life.

The family also had a strong sense of hospitality. Owing to the important trading route running through it, the area had much traffic. Jews with their wagons comprised part of it, and whenever a Jew passed through our village (something that happened quite often), he had to stop at my grandfather's inn, where someone would come outside to greet him with a glass of brandy, making the sign of shalam ${ }^{(\mathrm{b})}$ with one hand, and giving him the glass with the other. After that, the Jew would have to wash his hands and sit down at the table, which was always set.

${ }^{\mathrm{b}}$ [Maimon] The traditional Jewish greeting. 
Offering such hospitality while supporting a large family would not have seriously compromised my grandfather's material situation if only he had run his household better. His failures in this regard were the source of his misfortune.

My grandfather pinched pennies in small things but didn't pay enough attention to matters of [15] greater importance. For example, he thought it was wasteful to use wax or tallow candles at home. Narrow strips of resinous pine had to be inserted into cracks in the wall and lit at one end. The result, not infrequently, was fire damage far exceeding what candles would have cost.

There were no windows in the storage room for the beer, spirits, mead, herring, salt, and other things consumed daily at the inn. Light came in through simple openings in the walls. This easy access tempted the sailors and carriage drivers staying at the inn to climb into the room and get drunk on spirits and mead without paying for any of it. Even worse, these champion inebriates often fled upon hearing the slightest noise, because they were afraid of being caught in the act. Instead of taking a moment to shut off the tap, they would jump out of the holes they had come in through, [16] leaving the drink running. Whole barrels of spirits and mead were emptied out this way.

The barns were secured with wooden beams, not proper locks. As a result, and also because the barns were located quite far from the main living quarters, anyone could come in and make off with whatever he wanted, even a whole wagonload of grain. The sheep stalls were full of holes, and since all this was near the forest, wolves could slip in through the holes and kill as they pleased.

The cows often came back from grazing with their udders empty. In such cases, people would say-expressing a widely accepted superstitionthat a magic force had taken the milk from the cows, an evil turn they believed there was no way to prevent.

My grandmother, a good, simple woman, would lie down to sleep on the oven fully dressed, exhausted from her activities around the house. Her pockets were generally full of money, but she never knew just how much she had. The housemaid took advantage of this habit [17] and would empty out her pockets halfway. As long as the housemaid didn't get too greedy, my grandmother tended not to notice that anything was missing.

All these misfortunes could have been avoided by repairing the buildings, windows, shutters, and locks, as well as through proper management of the various sources of revenue that came with the lease, and by closely keeping track of income and expenses. But no one thought of doing any of that. And yet, when my father, a scholar partly raised in the 
city, wanted especially fine cloth for his rabbinical dress, my grandfather didn't hesitate to give him a long, reproachful lecture on the vanity of the world.

He would intone on those occasions: Our ancestors, they knew nothing of fashionable clothing, and they were certainly pious people. But you, you need a special shirt, leather pants-leather pants with buttons!-and everything else that goes with them. You'll make a beggar out of me. I'll [18] wind up in jail because of you. What a poor, unhappy man I am! What will become of me?

My father, in turn, would invoke the rights and privileges of the scholar class. He would also point out that if the lands and finances were being managed well, it wouldn't matter whether the people in my grandfather's household lived a little better. He would say that my grandfather's misfortunes resulted not from how much his household consumed, but rather from his letting others pillage it through his negligence. None of this swayed my grandfather. He simply couldn't tolerate change, so everything had to remain as it was.

In the village, my grandfather was seen as a wealthy man, which he would have been, had he known how to make use of his opportunities. Everyone envied and hated him for his wealth, even his own family. His estate keepers deserted him, his administrators sabotaged him in every conceivable way, his own domestic [19] workers and also ones he didn't know defrauded and stole from him. He was, in short, the poorest rich man in the world.

In addition to all of that, there were even greater personal calamities, which I cannot pass over in silence. The "pope" (i.e., the Russian priest) in my grandfather's village was an ignorant simpleton who could barely read and write. He was constantly at the inn getting sloshed with his congregants, the peasants, and he always put his drinks on a tab without ever intending to pay it. My grandfather finally grew tired of this, and resolved to stop letting him buy his drinks on credit. The pope was outraged, naturally, and wanted revenge.

He found a means repellent to most people, but which the Catholic Church in Poland had frequent recourse to at the time: accusing my grandfather of murdering a Christian and thereby bringing my grandfather before a hanging court. This happened in the following way. [20] My grandfather had secret dealings with a beaver trapper who was often in the area because of how good the trapping was on the Niemen River (beaver trapping remains an aristocratic privilege, and everything regarding it is supposed to go through the prince's court). One night, the beaver trapper came to my grandfather's house at about midnight, knocked on the door, and asked to speak to him. The trapper presented him with a 
heavy sack, and said with a strange expression on his face, "I've brought you a good one." My grandfather wanted to light a fire so that he could examine the beaver and negotiate its price. But the peasant told him that such dealings wouldn't be necessary: He should simply take the beaver, and they would come to an agreement later about what it should cost. My grandfather, suspecting nothing, took the sack, put it in a corner, and went back to bed. Having just fallen back asleep, he was woken again by very loud knocking on the door.

It was the scheming priest. He had come with several peasants from the village, who immediately began to search the house. They found the sack; [21] my grandfather trembled at the thought of the consequences, believing that someone had told the court about his secret beaver trading. Now he wouldn't be able to deny it. How horrified he was when the sack was opened, and inside there was no beaver at all, but a human corpse!

The peasants immediately tied my grandfather's hands behind his back, put his feet in blocks, threw him onto a wagon, and took him to the city of Mirz, where they brought him before the criminal judge. $\mathrm{He}$ was bound with chains and locked in a dark jail cell.

Under interrogation, my grandfather insisted that he was innocent, told the questioners exactly what had happened, and, of course, demanded that the beaver trapper be questioned as well. But the beaver trapper was already far away, not to be found. They searched everywhere for him, but this took too long for the bloodthirsty judge. He had my grandfather tortured three times in quick succession as the search was still going on. [22] However, my grandfather continued to insist that he was innocent.

Finally, they found the beaver trapper. He was questioned, and because he denied the whole affair he, too, was subjected to a torture test, during which he confessed everything. He admitted that he had discovered the dead body in the water and had brought it to the vicar to be buried. But the vicar had said to him: “There's plenty of time for that. You know how stubborn the Jews are in their beliefs, and that they are damned for all eternity. They crucified our Lord Jesus Christ. And they are still after Christian blood, which they want for their Easter festival. They need the blood for their Easter cakes, part of their celebration of the triumph of crucifixion. So if you can sneak this corpse into the house of the evil Jewish leaseholder, you will have done something very important. You will have to disappear afterward, but you can practice your trade anywhere." [23]

After giving this confession, the fellow was whipped. My grandfather was set free. The pope, though, remained the pope. 
As a permanent memorial to my grandfather's escape from death, my father wrote a sort of epic poem in Hebrew, which includes songs, narrates the whole event, and praises the goodness of God. It was established as a rule that the family would acknowledge the day of my grandfather's rescue. The poem would be read aloud, like the Book of Esther during the Festival of Haman. ${ }^{4}$ [24]

${ }^{4}$ The blood libel Maimon describes is discussed in Hillel Levine, The Economic Origins of Anti-Semitism: Poland and Its Jews in the Early Modern Period (Yale University Press, 1993). More recently, Adam Teller has noted that a blood libel occurred on the Radziwill estates in April 1752, which he tentatively suggests may be related to the one Maimon describes involving his grandfather, though the accounts do not quite tally, see Teller, Money Power, and Influence in Eighteenth Century Lithuania, p. 168 and 154n. The practice of writing a family or community megillah on the occasion of having averted disaster was not uncommon in early modern Askhkazi communities. 


\section{Earliest Childhood Memories}

MY GRANDFATHER LIVED THIS WAY for many years, in the same place where his ancestors had dwelled. His lease had become family property. Because of the Jewish ritual law of chasaka, which gave a person the right of ownership on property that had been in his possession for three years, and which was also recognized by the Christians in the region, no one who wanted to avoid excommunication could obtain my grandfather's lease through a hossoffa, i.e., by outbidding my grandfather. ${ }^{1}$ If owning the lease meant dealing with many difficulties, and even with acts of violence, it was, in the end, quite profitable. Thus my grandfather was able not only to live as a wealthy [25] man, but also to provide amply for his children.

His three daughters had sizeable dowries and were married off to good men. His two sons, my uncle Moses and my father Joshua, also married well. Because my grandfather was old, and worn down from overcoming so many hardships, he put his sons in charge of the household. Opposites in both temperament and inclinations-my uncle Moses was physically strong and intellectually weak, my father just the reverse-the brothers were not able to work together well. So my grandfather put my uncle in charge of a different village, keeping my father at his house, even though my father, with his scholarly vocation, wasn't particularly capable in economic affairs.

My father kept track of bills, signed contracts, attended to legal matters, and did other such things. My mother was a woman who, unlike him, enthusiastically embraced all of these activities. She was small in stature and, back then, still very young. [26]

I cannot proceed here without telling one particular anecdote, for it is my earliest childhood memory. I was about three years old. Because I was so bright and outgoing, I was very popular among the merchants who were always in town, and especially among the shaffars: the good gentlemen who managed both ships and the purchasing and transport of wares for great lords. These shaffars had all kinds of fun with me.

\footnotetext{
${ }^{1}$ The right that is described is presumptive not absolute, that is one who has, in this case, worked on a property for three years is presumed to have the right to continue doing so
} 
On account of my mother's small stature and her own lively spirit, these affable men gave my mother the nickname Kuza, which means "filly." 2 Having heard people use the name quite often, and since I didn't know the meaning of the term, I, too, called her Mama Kuza. My mother reproached me for this. She said that God punishes the person who calls his mother Mama Kuza.

One of the shaffars, a Herr Piliezki, came to our house daily to drink tea and won me over by occasionally giving me a piece of sugar. While he was having tea one morning, I, as usual, was waiting for some sugar. [27] He said that he would give me a piece only if I said Mama Kuza. Because my mother was there, too, I rejected his terms. So Herr Piliezki indicated to my mother that she should go into the next room. With her out of sight, I went up to Herr Piliezki and whispered in his ear: Mama Kuza. He wanted, however, that I say the name out loud and promised that he would give me a piece of sugar for every time I uttered it. And so I said: "Herr Piliezki wants that I should say Mama Kuza, but I don't want to say Mama Kuza, because God punishes people who say Mama Kuza.” I got three pieces of sugar.

My father's way of life at home was more refined, especially because he went on trading trips to Königsberg in Prussia, where he saw all kinds of beautiful and useful things. He was able to bring home pewter and brass tableware. We began to eat better than before, also to wear better clothes. Indeed, I was even dressed in damask. [28]

${ }^{2}$ Apparently, this had a sexual connotation. 


\section{Private Education and Independent Study}

My FATHER BEgAN TO READ the Holy Scripture with me when I was six. "In the beginning, God created heaven and earth." Here I interrupted him and asked: "But, Papa, who created God?"

Father: No one created God; he has existed from all eternity.

Solomon: Did he exist ten years ago?

F: Yes, indeed, he existed a hundred years ago.

S: So could God be a thousand years old?

F: Careful! God is eternal.

S: But he must have been born at some point? [29]

V: No, you little fool! God is eternal and eternal and eternal.-

I wasn't satisfied with this answer, but I thought Papa must know better than me, and I should leave it at that. ${ }^{1}$

At the beginning of childhood, when the intellect is still undeveloped but the imagination is already blooming, this kind of thought is quite natural.

The intellect seeks simply to grasp, the imagination to encompass. That is, the intellect seeks merely to understand how an object came into being, and it does so without taking into account whether or not we can properly represent objects whose genesis is known to us. The imagination, in contrast, seeks to encompass within an image, as part of a larger whole, that which has an origin we know. For example, an infinite series of numbers following a particular rule is, for the intellect, no better or worse an object than a finite series of numbers [30] following the same rule: both series have clearly defined properties by virtue of conforming

${ }^{1}$ Although Maimon's anecdotes generally turn out to be true when one puts them to the historical test, it should be noted that Jewish boys were traditionally initiated into biblical studies by reading the Book of Leviticus, for complex and partly obscure reasons. The Israeli literary critic Pinchas Lahover suggested that Maimon was comparing himself here to the great Greek philosopher-heretic Epicurus, who was said to have doubted Hesiod's creation myth as a boy, Diogenes Laertius, bk. 10. This is, perhaps, too clever, especially since Epicurus' puzzlement would seem to have been over the idea of chaos, and Maimon uses this incident to introduce a discussion of infinity and the imagination. See Lahover, "Introduction" to Solomon Maimon, Hayyei Shelomo Maimon (Tel Aviv, 1941), p. 28n2. 
to the rule. Only the finite series, however, exists for the imagination. The infinite series doesn't, because it cannot be encompassed within a complete whole.

Much later, when I was living in Breßlau, this idea led to a thought that I developed in an essay and that coincides with the foundations of Kantian philosophy, even though at the time, I knew nothing about that philosophy. (I showed the essay to Professor Garve.) ${ }^{2}$ I expressed this thought in more or less the following way: Metaphysical thinkers necessarily wind up contradicting themselves. The law of sufficient reason or origin is, according to Leibniz's own admission, an empirical principle-here he invokes Archimedes' experiment with the scale. And, indeed, one learns through experience that every single thing has its cause. But for this very reason, because every thing has its cause, nothing can be the first cause, i.e., a cause that has no cause. How, then, can metaphysicians derive the existence of a first cause from this principle? [31]

I later found this objection developed more rigorously in Kantian philosophy. For Kant's philosophy shows that the category of cause, or the form used in hypothetical doctrines about objects in nature-whereby their relation to each other is determined a priori-can only be applied to objects of experience through an a priori schema. The first cause-which contains a complete and infinite series of causes and, because the infinite can never be complete, a contradiction as well-is not an object of the intellect, but rather an idea of reason. Or rather, according to my own theory, it is an invention of the imagination. Not satisfied with simply understanding a law, the imagination seeks to encompass within an image the whole multiplicity that is subject to the law, even when that image runs counter to the law.

Another time, when I was reading the story of Jacob and Esau, my father recited a passage from the Talmud that says: Jacob and Esau divided all the goods of the world between them. Esau chose the goods of this life, [32] Jacob the goods of the future life, and because we are Jacob's descendants, we must renounce all worldly goods.

With some disdain, I replied that Jacob shouldn't have been such a fool; he should have chosen the goods of this world.

Unfortunately for me, the answer my father gave was to say: "You godless child!" And then he boxed my ear. The slap didn't clear away my doubts, but it did make me keep quiet.

\footnotetext{
${ }^{2}$ Chistian Garve (1742-98), one of the most prominent German philosophers of the eighteenth century, and one of the earliest and strongest critics of Kant's Critique of Pure Reason.
} 
Prince Radziwil, a great lover of hunting, once came to our village to watch a hunt, bringing with him his daughter (who would later marry Prince Rawurzky), as well as his whole courtly entourage.

The young princess and her ladies-in-waiting and servants took their midday nap in the very room where I used to sit behind the oven as a little boy. I was astonished by the splendor and brilliance of the courtly entourage. Utterly delighted, I stared at the beautiful people and their gold-and silver-trimmed [33] clothes; my eyes simply couldn't get enough of the scene. My father walked in just as I exclaimed, beside myself with joy: "How beautiful!" As a way of calming me and also reinforcing the principles of our faith, he whispered in my ear: "Little fool! In the future world, the duksel will stoke the pezure for us." (That is, in the future world, the princess will stoke the oven for us.)

It is almost impossible to describe what I felt upon hearing this idea. On the one hand, I believed my father and was very happy about the bliss that awaited us, even as I felt sorry for the poor princess, condemned as she was to carry out such miserable duties. On the other hand, though, I simply couldn't get my head around the notion that this pretty, rich princess in such magnificent clothes would stoke the oven for a poor Jew. I felt very confused until some game drove these thoughts from my head. [34]

From my very early childhood, I've had a great love of, and talent for, drawing. In my father's house, to be sure, I never got to see an example of this art. But on the title pages of various Hebrew books, I saw woodcuts of leaves, birds, and other such things. I enjoyed looking at these woodcuts immensely, and I tried to imitate them using little pieces of chalk and coal. What really helped me in this pursuit, though, was a Hebrew book of fables, in which the dramatis personae-the animals-were represented by woodcuts. ${ }^{3}$ I drew each figure with the greatest precision. While my father admired my aptitude, he also admonished me with these words: You should study the Talmud and become a rabbi. Whoever understands the Talmud-he understands everything.

Later, my father moved to H., where there was a manor house with several rooms covered in beautiful tapestries. Because the owner of the estate lived elsewhere and seldom visited the property, the rooms almost always stood empty. [35] My passion for painting went so far that, whenever I could, I would steal off to these rooms and make portraits of the figures on the tapestries.

\footnotetext{
${ }^{3}$ Maimon decorated the title page of his Hebrew manuscript, Hesheq Shelomo. The book of fables he describes is almost certainly Mashal Haqadmoni by the thirteenth-century Castilian poet Isaac ben Solomon Abi Sahula, which was first printed by Gershom Soncino in Brescia in 1490-91 and many times thereafter in both Hebrew and Yiddish.
} 
I was once found standing in front of these tapestries in the middle of winter. Half frozen, I had a piece of paper in one hand-for there was no furniture in the room-and was copying the figures on the walls with my other hand. My own estimation is that if I had stayed with it, I would have become a great painter, but not a very exact one. ${ }^{4}$ In other words, I would have been able to outline the main features of a painting with ease, but would not have had the patience to carry out the rest of the work with precision.

The little room in which my father studied contained a cabinet filled with books. He had forbidden the reading of all books except the Talmud. But that was not enough to stop me. My father spent most of his day dealing with domestic matters, and I made good use of this time. [36] Driven by my curiosity, I approached the cabinet, leafed through all the books in it, and, having already acquired quite a bit of Hebrew, found several of them to be more enjoyable than the Talmud.

This reaction was perfectly natural. Just consider: On the one side, there is the dry content of the Talmud, most of which is incomprehensible to a child. I am not even counting the parts that deal with jurisprudencethe laws of sacrifice, washing, prohibited foods, holidays, etc.-where the silliest rabbinical ideas are developed over many volumes with the most minute dialectics, and fatuous investigations are pursued with the greatest mental exertions imaginable. For example: How many white hairs can a red cow have and still be a red cow? ${ }^{5}$ Which sorts of sores require what kind of purification? Is it permissible to kill a louse or a flea on the Sabbath?6 (The former is allowed; the latter is a deadly sin.) Should the slaughtering of cattle be carried out at the throat or the tail? ${ }^{7}$ Did the high [37] priests put on their shirts first and then their pants, or was it the other way around ${ }^{8}$ If a man had a brother who died childless, thereby leaving the man, the jabam, obligated to marry his brother's widow, and then such a man were to fall off a roof and lie in the muck, would he have thereby fulfilled his duties, or would he not have? Obe iam satis est!?

\footnotetext{
${ }^{4}$ Maimon is probably making a statement about his intellectual style more generally. See his descriptions of his reading method of reading below, p. XYZ. \{ ? P Page ref needed

${ }^{5}$ See Babylonian Talmud, Tractate Avoda Zara, 24a.

${ }^{6}$ See Babylonian Talmud, Tractate Sabbath, 14a.

${ }^{7}$ See Babylonian Talmud, Tractate Hulin, 27a.

${ }^{8}$ See Babylonian Talmud, Tractate Sanhedrin, 49b.

${ }^{9}$ The last case is taken from Babylonian Talmud Yevamot 53b and Baba Kamma 27a. Maimon's "muck" is here a misogynistic euphemism. The hypothetical case discussed there involves a man falling off a roof and, without intent, penetrating his widowed sister-in-law. The rabbis rule that such an incident does not constitute sexual intercourse. The italicized phrase is another instance of Maimon's schoolboy Latin and means "but enough," (cf. Martial, Epigrams, vol. 1, (Cambridge: Harvard University Press, Loeb Classic Library), edited and translated by D. R. Shackleton Bailey, bk. 4, p. 327.)
} 
Compare these excellent tales, served up to and forced upon children to the point of revulsion; compare these tales, I say, with stories in which natural events are narrated in an edifying and pleasing manner, as well as with a knowledge of how the world works that both broadens one's perspective on nature and brings everything together in a well-ordered system. Compare stories that do this and more with the Talmud, and, truly, my preference will seem justified.

The best of these stories were as follows. There was a Hebrew chronicle published under the title Zemach David [צמח דוד], written by an intelligent chief rabbi in Prague named David Gans. (He was, in addition, the author of a book about astronomy, which will be discussed below. Gans had the honor of knowing Tycho Brahe personally [38], and of conducting astronomical research together with Brahe at the observatory in Copenhagen.) There was Josephus, who has been willfully misconstrued, as one can prove by citing certain pieces of evidence. ${ }^{10}$ There was a history of the persecution of Jews in Spain. And there was the book that held the greatest attraction for me, a work about astronomy. ${ }^{11}$

Here a new world opened up before me, and I set about exploring it with much enthusiasm. Imagine: There is a child of about seven who knows nothing of mathematics. He comes upon a book about astronomy. It intrigues him greatly, but no one can help him make sense of it (I couldn't tell my father about my interest, and even he wouldn't have been able to explain the book's content). How it must have excited the boy's knowledge-craving mind! His success further suggests that this was so.

Because I was still a child, and beds were scarce in my father's house, I was [39] permitted to sleep in a bed together with my old grandmother (in the room that served as the study). And because I had to read the Talmud during the day, and was not allowed to touch other books, I decided that evenings would be my time for astronomical study.

Thus, after my grandmother went to bed, I would light a fresh strip of pinewood, go up to the cabinet, and take out my beloved astronomy volume. My grandmother complained bitterly about this, because it was too cold for an old woman to be alone in bed. But I didn't listen; I would continue with my studies until the wood was used up.

${ }^{10}$ Maimon refers here to the popular medieval pseudepigrahic Jewish work Sefer Jossipon, rather than the historical Josephus. For the standard modern scholarly edition of the Hebrew edition, see David Flusser ed., Sefer Jossipon (Jerusalem: Magnes Press, 1981), 2 vols.

${ }^{11}$ R. David Gans' sixteenth-century work of astronomy was Nehmad Ve-naim, which Maimon almost certainly read in the Jessnitz edition of 1742 . For a somewhat dated but still useful biography of Gans, see Andre Neher, David Gans: Jewish Thought and the Scientific Revolution of the 16th Century (Oxford: Littman Library, 1986). 
Having followed this routine several evenings in a row, I finally came upon an account of the celestial sphere and its circles, devised to explain all astronomical phenomena.

In the book where I encountered it, this system was presented through a single diagram. But the author also gave his readers [40] the following good advice: Because, in an plane diagram, the various circles could only be shown with flat lines, readers should make themselves either a proper globe or a sphera armillaris in order to understand the ideas better.

I thus decided to build such a sphera armillaris by twisting rods together. After I had done so, I was able comprehend the whole book. Because my father couldn't know anything about these activities, I always hid my sphera armillaris in a corner of the bookcase before going to bed. The problem was that my grandmother often watched me as I was completely absorbed in reading. Furthermore, she sometimes saw me looking at circles fashioned out of braided rods, and that were stacked on top of each other crosswise. She became terribly worried as a result of this, believing nothing less than that her grandson had lost his mind. [41]

And so she reported to my father what she had seen. She also showed him where I kept my magic instrument. Having quickly surmised its purpose, he had me summoned. When I appeared, he questioned me with the following words:

F: What kind of toy have you made for yourself?

S: It is a kader. ${ }^{(a)}$

$\mathrm{F}$ : What is the meaning of this?

I proceeded to tell him how the circles made celestial phenomena comprehensible. My father was, to be sure, a fine rabbi, but he had no special talent for science and could not understand all that I tried to explain to him. He was especially confused by the relationship between my sphera armillaris and the diagram in the book. How could [42] spheres be rendered as flat lines? He could, however, recognize this much: I was quite certain of myself.

He scolded me for breaking his rule against reading anything other than the Talmud. Yet inwardly he was very pleased by the fact that without any mentoring or prior knowledge, his young son had been able to carry out a whole scientific project. And with that, the interrogation came to an end. [43]

a [Maimon] The Hebrew term for globe. 


\section{Jewish Schools. The Joy of Being Delivered from Them Results in a Stiff Foot}

My BRother Joseph AND I were sent to school in Mirz. Joseph, who was about twelve at the time, lodged with a famous schoolmaster named Jossel. This man was every student's nightmare, the scourge of God. He handled the boys placed in his care with a monstrous brutality whipping them for the slightest offense until the blood flowed, and not infrequently tearing off ears and gouging out eyes. When the parents of his unfortunate victims came to complain, he would hurl rocks at them or whatever was handy, regardless of who the parents were. He would then chase them out of the room with his walking stick, all the way back to where they lived. His charges [44] became either idiots or great scholars. I was only seven at the time, and was sent to a different schoolmaster.

There is one story that I must tell here. It is partly an illustration of deep brotherly love, but it should also be seen as evoking the mentality of a child hoping for relief from misfortune, while simultaneously fearing that the misfortune will grow worse. One day, I came home from school with eyes red from crying (no doubt I had had good reason to cry). My brother noticed and asked what had happened. At first, I didn't want to answer, but finally I confided: "I was crying because we aren't allowed to tell tales out of school." My brother understood me quite well and was outraged, so much so that he wanted to confront my teacher. I asked him not to, since the teacher would probably punish me for telling tales out of school. [45]

Now I must say something about the general condition of Jewish schools. ${ }^{1}$ Most often the school is a smoky shack with students scattered around, some perching on benches, others sitting on the dirt floor. The teacher, with a filthy shirt on his back, sits on his desk commanding his regiment, all the while holding between his legs a bowl of tobacco, which he works over into snuff with a pestle as massive as the club of Hercules. His assistants conduct drill sessions in their own corners of the room,

\footnotetext{
${ }^{1}$ Maimon's description of Jewish schools here is an early classic of the enlightened critique of traditional Jewish education, which was a central plank of the Haskala.
} 
each one ruling over his subjects just as the teacher himself does: as an absolute despot. The children bring breakfast and snacks to school, and the teachers keep the lion's share of the food for themselves. Sometimes, in fact, the poor boys get nothing at all. And if the boys want to avoid facing the wrath of these tyrants, they won't complain. Children are locked up here from morning until evening. They have free time only on Fridays and on the afternoon of the first of the month.

As to the actual curriculum, at least the Hebrew scripture is still [46] studied quite properly. The method for acquiring the Hebrew language, in contrast, is quite odd. Teachers don't go over the principles of grammar. Instead, the rules must be learned ex usu: that is, by translating the Holy scripture. As a result, students are much like the ordinary person who develops an incomplete understanding of grammar through the normal use of his mother tongue. Nor is there a Hebrew dictionary. Students begin interpreting the Holy Scripture right away; and since the Holy Scripture is divided into as many sections as there are weeks in the year, students can read through the books of Moses-read every Saturday in synagogue-in a year. Thus, each week, students interpret several verses from the beginning of the section for that week, making every possible grammatical mistake as they do so. But there are no better alternatives. For the students' native Yiddish-Polish is full of grammatical deficiencies, and so when Hebrew readings are interpreted in the students' native language, the Hebrew they learn is naturally of the same [47] poor quality. In this way, then, students gain just as little knowledge of the Hebrew language as they do of the Holy Scripture's content.

In addition, Talmudists have buried the Holy Scripture under all manner of strange ideas, and our ignorant teachers confidently believe that the Holy Scripture can have no meaning other than the ones these explicators assign it. Students are compelled to share this belief, with the result that the correct interpretation of words necessarily gets lost. For example, where the first book of Moses reads "Jacob sent messengers to his brother Esau," Talmudists like to claim that the messengers were angels. Now while the Hebrew word malachim can, to be sure, mean both "messengers" and "angels," these miracle-chasers have opted for second meaning simply because the first doesn't suggest anything miraculous. The students, in turn, come to think that malachim means nothing other than "angels," and thus the primary meaning of "messenger" gets lost. It is only by studying on one's own, and by reading Hebrew primers and philological commentaries on the Holy Scripture (such as [48] David Kimichi's and Ibn Ezra's), which just a few rabbis use, that one can, bit by bit, achieve a correct understanding of the Hebrew language and work toward sound exegetical practices. 
Children are condemned to such a hell precisely when their youth is in full bloom. So one can easily imagine the excitement with which they look forward to being out of school. On high holidays, my brother and I would be picked up and brought home. During one of those trips, the following event took place; it would prove to be of crucial significance for me.

My mother had come before the holiday of Shavuot to the town where we were going to school, because she needed to buy various things for her household. Afterward, she took us home. Being freed from school, coupled with the sight of that beautiful person all done up in her best clothes, delighted us so much that we became downright reckless. As we were approaching our hometown, my brother boldly leapt out of the wagon and ran the rest of the way on foot. I wanted to do [49] the same but wasn't strong enough. I fell hard and landed next to the wagon with my legs caught between the wheels. One of the wheels ran over my left leg, crushing it horribly. They brought me home half-dead. My foot seized up and was completely immobile.

A Jewish doctor was consulted. He hadn't, to be sure, studied medicine at a university or earned a regular degree; rather, he had acquired his medical knowledge by working under a doctor and by reading some Polish medical books. But he was still a very good practical physician who had healed many patients. He had no supply of medicine, he said, and the nearest pharmacy was twenty miles away. Thus he couldn't prescribe a cure using his normal method. In the meantime, though, we should make use of an easy household remedy. Someone should kill a dog, and I should put my injured foot into the body. Repeating this several times [50] would definitely bring about some relief. His order was followed, with the success that we had hoped for. After several weeks, I could move my foot and put weight on it. My recovery continued until my foot was completely healed.

I think that it wouldn't be a bad thing if doctors paid more attention to household remedies, for they are often used with great success in parts of the world without regular doctors and pharmacies. Doctors might even make special trips to these areas to learn about such methods. I know of many instances of effective treatment that cannot be explained away. All this, however, in passing. I now return to my story. [51] 


\section{My Family Is Driven into Poverty, and an Old Servant's Great Loyalty Costs Him a Christian Burial}

As I've SAID, MY FATHER USED to go on trading trips to Königsberg in Prussia. During one such trip, he bought several barrels of salt and herring, which he had loaded onto a ship that Prince Radziwil owned. When, upon his return, he went to pick up his goods, a customs official named Schachna flatly refused to allow it. My father's response was to show him the receipt for the goods. But the official just snatched the receipt and threw it into the fire.

My father was now forced to initiate what would be long and costly legal proceedings, which in fact he had to postpone for a year. The next time he traveled to Königsberg, he obtained a receipt from the toll bureau documenting that, [52] under Schachna's supervision, the goods in question had been loaded onto Prince Radziwil's ship. On the basis of this receipt, the official was summoned to appear before court. He decided, however, that it would be best not to try to defend himself, and my father won the case on the first, second, and third levels of judicial authority. But the Polish justice system was in such bad shape then that my father had no way to enforce the verdicts. He was never even reimbursed for the costs of the trial he had won.

Moreover, my father had made an enemy of Mr. Schachna, who now tried to undermine him in all sorts of ways. And things very went well for Schachna in this. Through various kinds of intrigue, that cunning scoundrel managed to get himself appointed by the prince to be the chief administrator of all the prince's estates. Having resolved to ruin my father, he waited for the right moment to exact his revenge.

$\mathrm{He}$ did not have to wait long. Indeed, a certain Jew who went by the name of the land he leased, Schwersen, and who was known as the greatest [53] villain in the region, soon offered him a helping hand. This Schwersen was a great ignoramus. He couldn't even understand Yiddish and hence resorted to using Russian. His primary way of doing business was to look around the area for the most profitable leases, and then to acquire these leases by outbidding the leaseholders and bribing the estate administrators. Ignoring the chasaka laws, he drove away the legitimate 
leaseholders and thereby increased his wealth. He was prosperous and happy, and in that state he reached an old age.

Having long had his eye on my grandfather's lease, this villain had been waiting for the chance to make it his own. Unfortunately for us, my granduncle Jacob, who lived in another of the villages included in grandfather's lease, had been forced to go into debt to the very same miscreant. When my great uncle was unable pay off his debt-about fifty-six dollars-by the deadline, Schwersen wasted no time in confronting him. Schwersen brought some servants [54] along and threatened to take my great uncle's cauldron, his sole possession of value. Utterly overwhelmed, my great uncle snuck the cauldron onto a wagon, drove it as fast as he could to my grandfather's house, and, unbeknownst to any of us, hid it in the bog closest to the back of the house. His creditor, who had followed him on foot, soon arrived at my grandfather's residence. He had the whole area thoroughly searched but couldn't find the cauldron. Seething over his failed ploy, and hungry for revenge against my grandfather, who, he believed, had thwarted his efforts, Schwersen rode to town. He took along a handsome gift for the estate administrator, and he offered him twice as much lease-money as my grandfather had been paying as well as an annual gift.

The administrator was pleased to have such an offer, and remembering the insult that my father, a Jew, had dealt him, a Polish nobleman, through the above-mentioned lawsuit, he [55] wrote out a new contract for the odious man on the spot. He not only transferred the lease, along with all its attendant rights, before my grandfather's lease time had ended, he also robbed my grandfather of all his property: barns full of grain, cattle, etc. He then split the booty with the new leaseholder.

In the middle of winter, my grandfather had to leave his home with his whole family and wander from place to place without knowing where he should try to settle. Our departure was a tragic affair. The whole neighborhood lamented our fate.

A loyal eighty-year-old servant named Gabriel, who had held my grandfather in his arms when my grandfather was a child, insisted on coming with us. He was warned about the harshness of the season, our present misfortunes, and our uncertain future. But nothing made a difference. He lay down in front of the gate through which our wagons had to pass and wailed for so [56] long that we felt compelled to bring him along. He did not travel far with us, however. His advanced age, the worry caused by our misery, and the brutal weather soon dealt him the final blow. He died, and since we had hardly covered more than a few miles, and no Catholic or Russian congregation would consent to give him a churchyard burial (he was Prussian and a Protestant), he was buried in an open field at our expense. [57] 


\section{New Residence, New Misery. The Talmudist}

AND SO WE WANDERED through the countryside the way the Israelites had wandered through the deserts of Arabia, without knowing where, when, or how we would find a place to make a new home. Finally, we arrived at a village that was owned by two lords. The part belonging to one was already leased; the other part couldn't be leased because the other lord had not yet built a house. Weary of traveling around in winter with his whole family, my grandfather decided on the spot to lease this still unbuilt house and all that went with it. While the house was being constructed, we would make do. Thus we stayed in a barn for a time. Meanwhile, the other leaseholder did everything he could to prevent us from settling into this place. [58] Nothing he tried worked. The building was finished; we moved in and began to organize our affairs.

Here, unfortunately, nothing seemed to go right for us. Not only were we plagued with setbacks, but my mother, who had a lively disposition and liked being active, found little to do and grew bored. Coupled with her worries about whether we would have enough to eat, the problem of boredom drove my mother into a melancholic state, from which she ultimately plunged into outright insanity. She remained this way for several months. Nothing helped. Finally, my father came up with the idea of taking her to Novgorod, where there was a famous doctor who specialized in healing such mental illnesses.

I don't know what mode of therapy this expert used, being too young at the time to ask or even to want to ask about it. But I can say this much with certainty. His treatment was successful, as it was with most patients of my mother's type. My mother went home refreshed and healthy, [59] and she didn't suffer a relapse.

Just after this episode, I was sent to Iwenz, ${ }^{1}$ fifteen miles away from where we lived. It was there that I began to study the Talmud.

For our people, the study of the Talmud is the primary mark of an educated upbringing. Wealth, outstanding physical abilities, and talents

\footnotetext{
${ }^{1}$ Present-day Ivyanets near the Valozhyn region of Belarus, where the leading yeshiva of the nineteenth century, Etz Hayyim, was founded a generation later by Rabbi Hayyim of Volozhin in 1803.
} 
of all kinds may be valuable and to some extent respected, but nothing, in our view, surpasses the worth of a good Talmudist. He has the first claim to all the offices and honors in the community. When he enters a gathering, all rise to greet him, whatever his age and class, and he is given the best seat. He is the common man's spiritual guide, lawmaker, and judge. Whoever fails to show such scholars sufficient reverence is, according to dictum of Talmudists, damned for all eternity. The common man is not allowed to do the slightest thing [60] that has not been judged by a scholar to be consistent with the law. Religious customs, permitted and forbidden foods, marriage and divorce-all these matters are not only defined by an enormous number of rabbinical laws, but also through rabbinical judgment, which derives answers for specific cases from these general laws.

A rich merchant, leaseholder, or professional man who has a daughter will do everything he can to attract a good Talmudist as his son-in-law. No matter if the Talmudist is misshapen, sickly, or otherwise ignorant. He stands above all others. According to the standard arrangement, the future father-in-law of such a cynosure must pay the phoenix's parents a negotiated sum at the time of the engagement, along with the dowry meant for the daughter, and he must initially provide the bride and her husband with food, clothing, and shelter. During this time, the couple gets the interest from the money set aside for the dowry, and the learned son-in-law continues his studies [61] at his father-in-law's expense. Afterward, the Talmudist gains full control of the dowry. He may be promoted to a scholarly office, or he can spend his whole life in erudite indolence. In either case, the woman takes care of running the household and all other economic responsibilities. She will be satisfied if, in exchange for all her labor, she can share to some degree in her husband's fame and his future blessedness.

The Talmud is studied as unsystematically as the Holy Scripture. The language of the Talmud is a mixture of various Oriental languages and dialects. In fact, instances of Greek and Roman also occur. There is no dictionary in which one can look up all of the expressions and phrases that the Talmud contains. Worse still: Because the Talmud doesn't have the marks that denote vowels in Hebrew and Aramaic, one doesn't even know how the words that aren't pure Hebrew should be read. Like the language of the Holy Scripture, that of the Talmud is learned simply [62] through frequent translating. This is what makes up the first level of Talmudic study.

For a while, the teacher guides the student through translations. Eventually, the student begins to read and interpret the Talmud on his own. The teacher assigns a section of the Talmud that contains a unifying logic, and the student must explain the section within a certain time limit. Either the student is familiar with the terminology of the section from previous 
reading, or else the teacher, acting as a dictionary, clarifies the words and phrases. But the student himself must explain the content and whole logic of the assigned section. This is the second level of Talmudic study.

The two commentaries often included in the text serve mainly as guides. One of them was written by Rabbi Salomon Isaak, a man of great philological learning, broad ranging and thorough [63] Talmudic insight, and uncommon precision in laying out ideas. The other appeared under the title Thosphot (addenda) and was coauthored by many rabbis. ${ }^{2}$ Its genesis is quite remarkable. A number of the most prominent rabbis decided to study the Talmud together, with each of them choosing part of the Talmud and studying that part until he had it memorized and felt he had understood it completely. Then the rabbis would come together and study the Talmud as a group, proceeding in the order of its parts. As soon as they had read the first part aloud, thoroughly explained it, and corrected it using the internal logic of the Talmud, a rabbi would point to a part in his section that appeared to contradict the part under discussion. Immediately thereafter, a different rabbi would point to a passage in the part he had mastered, which, because of a distinction or condition not expressed in the first part, seemed capable of resolving the contradiction. [64] The resolution of such a contradiction would occasionally lead a third rabbi to discover another contradiction, which a fourth would then attempt to resolve. This process would go on until the part that came first had, by consensus, been explained and clarified.

The Talmud is a large and sprawling work consisting of many heterogeneous parts that define the same object in different ways, so it is easy to see why great intelligence is necessary to arrive at its governing principles. These principles can be used, if one is consistent in one's methodology, to reach many correct conclusions.

In addition to the two commentaries mentioned above, there are many others. They pursue many matters even further, and some even correct those two. Every rabbi who is sharp enough should be seen as a living Talmudic commentary.

But what demands the greatest mental effort is preparing a selection from the Talmud or [65] a code of the laws it yields. This requires not simply intelligence, but also the most systematic mind. Here Maimonides has no equal, as can be gathered from his code Jad Hachasaka.

The third and final level of Talmudic study is that of disputation: an endless argument about the book without any aim or goal. Acumen,

\footnotetext{
${ }^{2}$ Rabbi Shelomo (Solomon) ben Isaac (1040-1105), the foremost Jewish medieval commentator, is generally known by his acronym Rashi. The Tosafists flourished in the following century and included Rashi's students and descendants. Maimon's description of their work is brief but precise and probably the first such description in German.
} 
eloquence, and impertinence are of decisive importance here. This mode of study was once a common practice at advanced Jewish schools, but in our time it has become much less widespread. It is a kind of Talmudic skepticism, and, as such, it runs largely counter to practical, systematic study. [66] 